\title{
Lower Permian brachiopods from Oman: Their potential as climatic proxies
}

\author{
L. Angiolini ${ }^{1}$, D. P. F. Darbyshire ${ }^{2}$, M. H. Stephenson ${ }^{3}$, M. J. Leng ${ }^{2 \& 4}$, \\ T. S. Brewer ${ }^{5}$, F. Berra ${ }^{1}$ and F. Jadoul ${ }^{1}$
}

${ }^{1}$ Dipartimento di Scienze della Terra 'A. Desio', Università degli Studi di Milano, Via Mangiagalli 34, Milano, 20133, Italy.

E-mail: lucia.angiolini@unimi.it

\author{
${ }^{2}$ NERC Isotope Geosciences Laboratory, British Geological Survey, Keyworth, Nottingham, NG12 5GG, UK. \\ ${ }^{3}$ British Geological Survey, Keyworth, Nottingham, NG12 5GG, UK. \\ ${ }^{4}$ School of Geography, University of Nottingham, Nottingham NG7 2RD, UK. \\ ${ }^{5}$ Department of Geology, University of Leicester, University Road, Leicester, LE1 7RH, UK.
}

\begin{abstract}
The Lower Permian of the Haushi basin, Interior Oman (Al Khlata Formation to Saiwan Formation/lower Gharif member) records climate change from glaciation, through marine sedimentation in the Haushi sea, to subtropical desert. To investigate the palaeoclimatic evolution of the Haushi Sea we used O, C, and Sr isotopes from 31 brachiopod shells of eight species collected bed by bed within the type-section of the Saiwan Formation. We assessed diagenesis by scanning electron microscopy of ultrastructure, cathodoluminescence, and geochemistry, and rejected fifteen shells not meeting specific preservation criteria. Spiriferids and spiriferinids show better preservation of the fibrous secondary layer than do orthotetids and productids and are therefore more suitable for isotopic analysis. $\delta^{18} \mathrm{O}$ of $-3 \cdot 7$ to $-3 \cdot 1 \%$ from brachiopods at the base of the Saiwan Formation are probably related to glacial meltwater. Above this, an increase in $\delta^{18} \mathrm{O}$ may indicate ice accumulation elsewhere in Gondwana or more probably that the Haushi sea was an evaporating embayment of the Neotethys Ocean. $\delta^{13} \mathrm{C}$ varies little and is within the range of published data: its trend towards heavier values is consistent with increasing aridity and oligotrophy. Saiwan $\mathrm{Sr}$ isotope signatures are less radiogenic than those of the Sakmarian LOWESS seawater curve, which is based on extrapolation between few data points. In the scenario of evaporation in a restricted Haushi basin, the variation in $\mathrm{Sr}$ isotope composition may reflect a fluvial component.
\end{abstract}

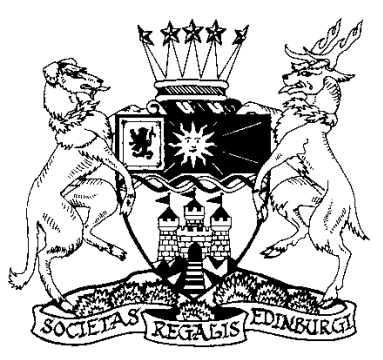

KEY WORDS: carbon, cathodoluminescence, geochemistry, Gondwana deglaciation, Haushi basin, late Sakmarian, oxygen, strontium isotopes, ultrastructure.

Articulated brachiopod shells (Subphylum Rhynchonelliformea) are known to record the primary geochemical signal of ancient seawater, as the low-Mg-calcite (LMC) of their shell is generally resistant to diagenetic change (i.e., Compston 1960; Lowenstam 1961; Popp et al. 1986; Veizer et al. 1986, 1999; Korte et al. 2003, 2005). Articulated brachiopods secrete a two- or three-layered calcite shell below an outer proteinaceous periostracum. The primary layer is prismatic and generally has carbon and oxygen isotope ratios that are lower than expected for equilibrium, whilst the secondary layer is fibrous or laminar and is thought to precipitate in isotopic equilibrium with ambient seawater (Lowenstam 1961; Brand 1989; Grossman et al. 1991; Brand et al. 2003). The tertiary layer, when present, is prismatic and locally confined inside the shell. Vital effects are generally not recorded in the slow-growing secondary layer of brachiopod shells, though Carpenter \& Lohmann (1995) found differences within individual specimens in the thin outer primary layer and in specialised areas of the secondary shell. Curry \& Fallick (2002) recorded different $\delta^{18} \mathrm{O}$ values from the dorsal and ventral valves of a terebratulid species from the mouth of a narrow cave on the Otago Peninsula (New Zealand). Auclair et al. (2003) found deviations of several per mil from expected equilibrium values in the outer part of the secondary layer of one punctate intertidal brachiopod shell. Very recently, Parkinson et al. (2005) have shown that $\delta^{18} \mathrm{O}$ values from the fibrous secondary or prismatic tertiary shell layers of recent Terebratulida (including the same species already analysed by Curry \& Fallick (2002) and Auclair et al. (2003) and Rhynchonellida species were in oxygen isotopic equilibrium with ambient seawater and were relatively unaffected by shell specialisation. Also, Parkinson et al. (2005) found no significant difference in $\delta^{18} \mathrm{O}$ compositions between ventral and dorsal valves. However, carbon isotope composition can be highly variable and possibly subjected to a vital effect produced by metabolic prioritisation. Therefore it is the innermost and, when possible, non-specialised secondary layer of fossil brachiopod shells with similar ultrastructures to modern Terebratulida and Rhynchonellida that should be sampled for stable isotope ratios.

The isotope composition of carbon $\left(\delta^{13} \mathrm{C}\right)$, oxygen $\left(\delta^{18} \mathrm{O}\right)$ and strontium $\left({ }^{87} \mathrm{Sr} /{ }^{86} \mathrm{Sr}\right)$ in ancient seawater has varied through time in response to palaeoenvironmental evolution. Brachiopods are among the best shells from which to obtain 

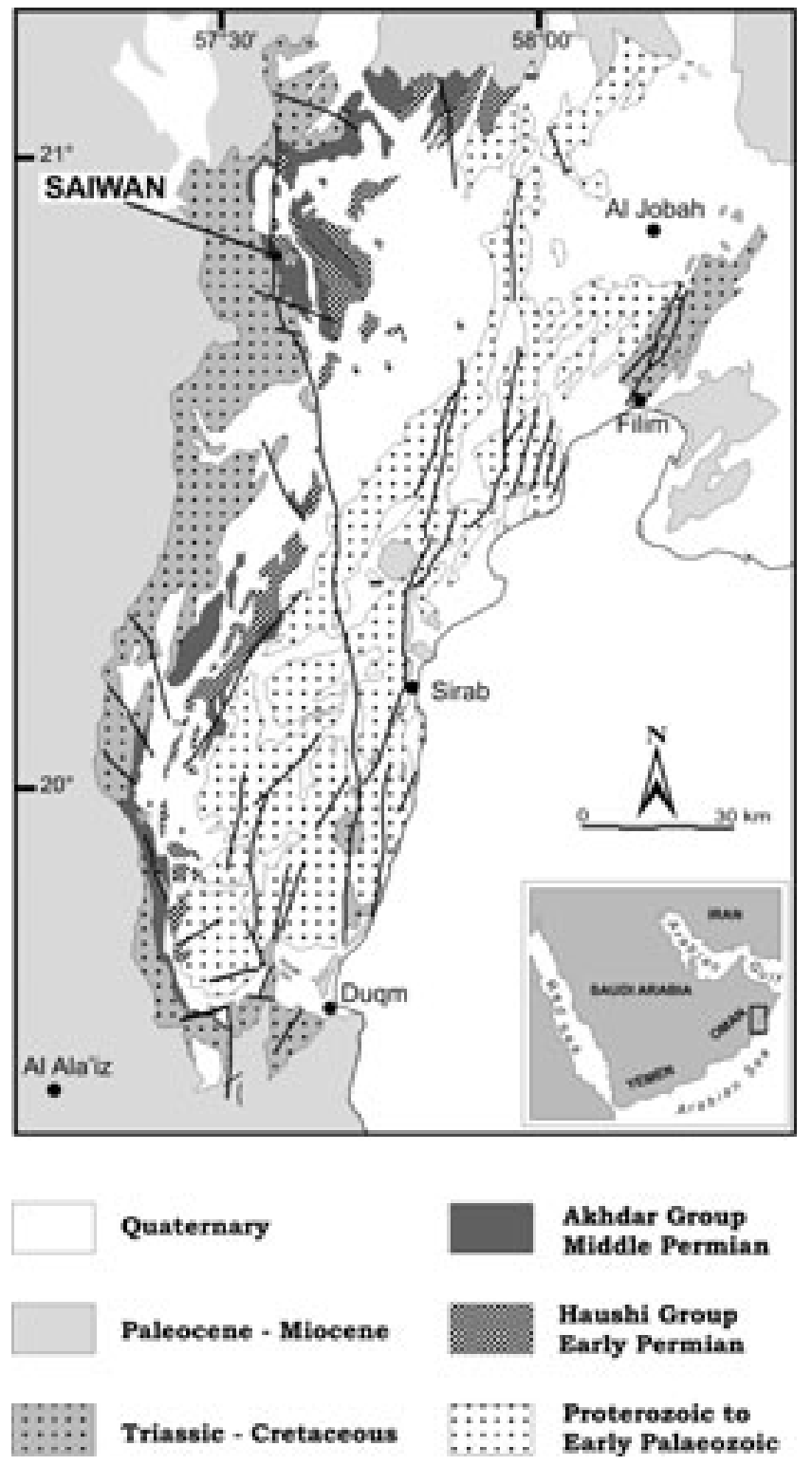

Figure 1 Geological sketch map of the Haushi surface outcrop area in central interior Oman, with location of the Saiwan type section (modified from Angiolini et al. 2003a).

the primary geochemical signal and environmental information. This present study assesses the degree of diagenetic alteration by scanning electron microscopy (SEM), cathodoluminescence (CL), and geochemistry from a suite of brachiopods from the Lower Permian Saiwan Formation, Interior Oman. It then investigates the evolution of the Haushi sea, the body of water in which the Saiwan Formation was deposited, using $\mathrm{O}, \mathrm{C}$, and $\mathrm{Sr}$ isotopes of brachiopod shells collected bed by bed from the Saiwan Formation.

\section{Geological setting}

In central Interior Oman, Lower Permian strata are represented by the Al Khlata and Saiwan formations in surface outcrop (Fig. 1) and by the Al Khlata Formation and the lower and middle Gharif members in the subsurface. Correlation of these units, particularly the Saiwan Formation and the lower Gharif member, has only recently been understood based on brachiopod and palynomorph biozones (Angiolini et al. 2006).

The surface Saiwan Formation was introduced by Dubreuilh et al. (1992) for the marine fossiliferous sandy limestones, previously informally named the Haushi limestone by Hudson \& Sudbury (1959). The Saiwan Formation was deposited in the Haushi sea, south of the Neotethys Ocean rift shoulder (Fig. 2), and overlies both the glacigene diamictite of the Al Khlata Formation and the basal sandstones of Osterloff et al. (2004). At its top, the Saiwan Formation is believed to be bounded by an unconformity, separating it from the overlying continental Gharif Formation sensu Dubreuilh et al. (1992). Angiolini et al. (2003a) showed the evolution of a pioneering cold-water brachiopod palaeocommunity (Pachycyrtella palaeocommunity) at the base of the formation, followed by a more mature secondary palaeocommunity of a more diversified marine biota above. The Pachycyrtella palaeocommunity is characterised by: (1) a random distribution pattern over a limited area; (2) clustering in groups; (3) numerical dominance $(>85 \%)$ of $P$. omanensis; and (4) suspension feeding. Palaeoecological analyses (Angiolini et al. 2003a, 2006) suggested that these brachiopods thrived on a mobile arenitic substrate at shallow depths around or just below the fair weather wave base $(10-20 \mathrm{~m})$. The brachiopods also had rapid rates of reproduction and growth ( $r$-strategy), reached maturity early and had high mortality rates in the juveniles (Angiolini et al. 2003a). The disappearance of this basal palaeocommunity is related to a drastic change in the physical environment, recording the interplay of final Gondwanan deglaciation and initial Neotethys opening (Angiolini et al. 2003a). The secondary palaeocommunity rapidly reached high diversity, testifying to a significant climatic amelioration and more stable environmental conditions. Both the Pachycyrtella palaeocommunity and the overlying secondary palaeocommunity are dominated by large spire-bearing brachiopods, suggesting a high nutrient setting (Perez-Huerta \& Sheldon 2006). Eutrophic condition at the base of the Saiwan Formation evolved upward into more oligotrophic conditions.

Stephenson \& Osterloff (2002) and Stephenson et al. (2005) studied equivalent beds in the subsurface of South Oman. In this region, the equivalent-aged rocks comprise clastic sandstones of terrestrial origin, suggesting that the Haushi sea did not transgress as far south as South Oman. However, the palynological succession allowed detailed metre-by-metre reconstruction of vegetational changes within the deglaciation period. In the lowest part of the South Oman lower Gharif member, a cold climate 'fern' wetland palaeocommunity was present, probably on lowland outwash alluvial plains, whilst on the surrounding uplands or better-drained ground, a primitive conifer community developed (Stephenson et al. 2005; Stephenson \& Osterloff 2002). Later in the postglacial period these communities were replaced. In the lowland alluvial plains, a cycad-like and lycopsid vegetation developed, while in the uplands or better drained areas a taeniate- and nontaeniate bisaccate pollen producing glossopterid or other gymnospermous flora was established. Slightly later, restricted marine conditions occurred in parts of the sedimentary basin in South Oman. Within the bodies of brackish or salt water, an ephemeral microflora and fauna (indicated by rare acritarchs and microforaminiferal linings) developed. Evidence from the carbon isotope composition of bulk organic material from the $\mathrm{Al}$ Khlata and lower Gharif formations show a trend which is thought to reflect postglacial warming, since there is sedimentological and palaeontological evidence of deglaciation in the sequence (Stephenson et al. 2005).

The age of the limestones of the lower Gharif member, the subsurface equivalent of the Saiwan Formation, was established in subsurface borehole core sections of Wafra-6 and Hasirah-1 around $100 \mathrm{~km}$ to the west of the Saiwan Formation outcrop (Angiolini et al. 2006). Samples from two horizons contained the fusulinids Pseudofusulina inobservabilis Leven, 


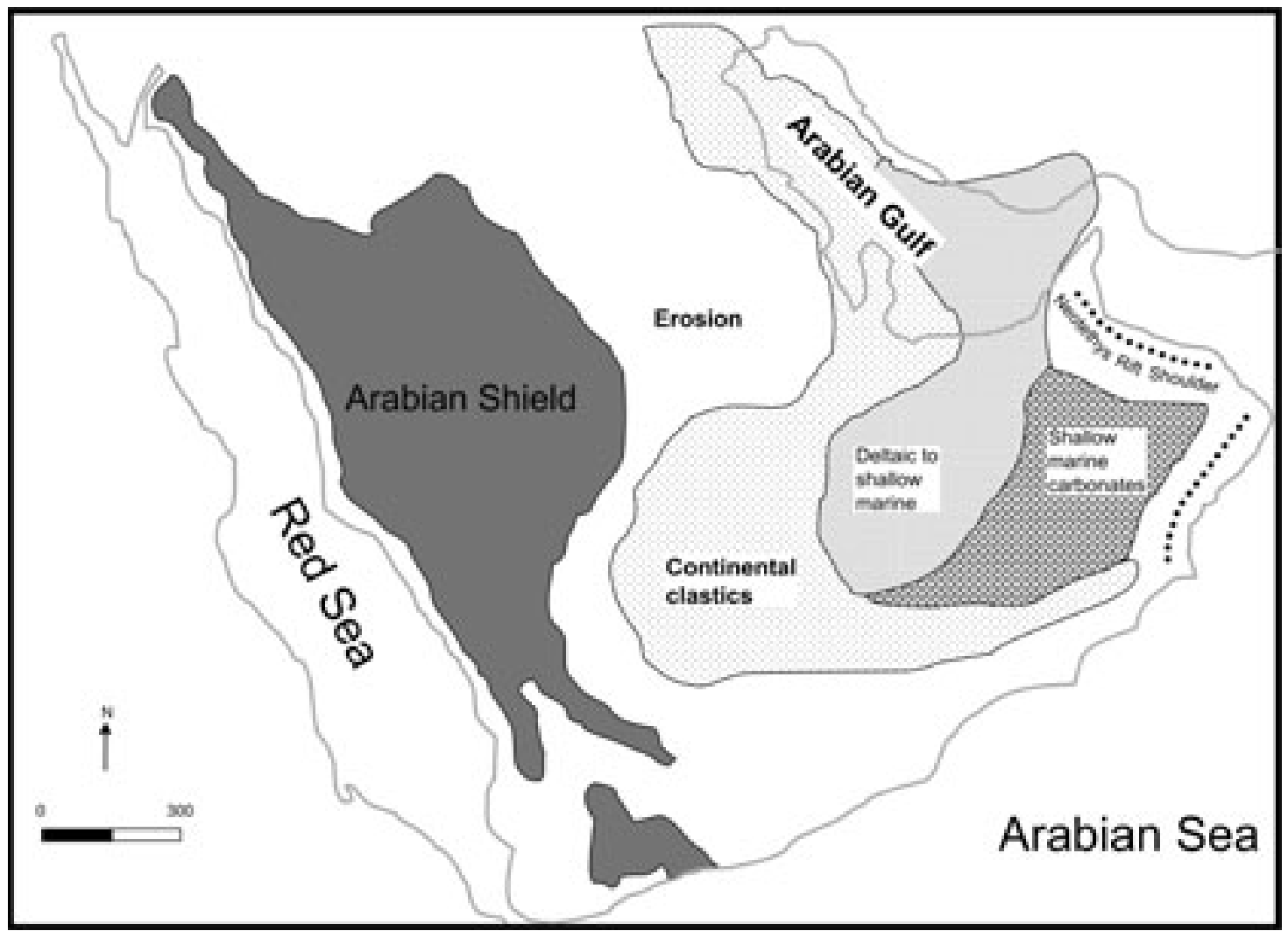

Figure 2 Palaeoenvironmental map of the Haushi sea transgression in interior Oman at Sakmarian times. Modified after Konert et al. (2001).

1993, Pseudofusulina ex gr. karapetovi karapetovi Leven, 1993 , Pseudofusulina aff. karapetovi tezakensis Leven, 1993, Pseudofusulina licis Leven, 1993, Pseudofusulina incompta Leven, 1993, Pseudofusulina (?) sp., Pseudofusulina incompta Leven, 1993, Pseudofusulina cf. insignis Leven, 1993, Pseudofusulina aff. karapetovi tezakensis Leven, 1993 and Pseudofusulina cf. inobservabilis Leven, 1993. This assemblage is similar to the 'Kalaktash complex' of Afghanistan, Central Pamir and Karakorum (Leven 1993, 1997; Gaetani et al. 1995), which is Sakmarian based on species common to the standard Lower Permian stages of the Russian Urals. Fusulinids are currently the most widely used biostratigraphic tools for correlating the bases of the Sakmarian and Artinskian stages in the Russian Platform and Urals, thus the presence of the Pseudofusulina assemblage in the subsurface equivalent of the Saiwan Formation suggest a high level of certainty for the proposed Sakmarian age.

\section{Material and methods}

Thirty four articulated brachiopod specimens from the Pachycyrtella palaeocommunity (bed OL14 Fig. 3 ) and the overlying secondary ecological palaeocommunities (beds OL15-OL18 Fig. 3) of the Saiwan Formation were selected for ultrastructural analysis. Of these, 31 underwent subsequent geochemical and isotope analyses and the data are shown in Table 1. The analysed brachiopods belong to seven species of the orders Productida (Reedoconcha permixta), Orthotetida (Derbyia haroubi Angiolini et al. 1997), Spiriferida (Neospirifer (Quadrospira) aff. hardmani (Foord, 1890)) and Spiriferinida (Pachycyrtella omanensis Angiolini, 2001, Pachycyrtella sp. A, Punctocyrtella spinosa Plodowski, 1968, Subansiria cf. ananti Singh, 1978). The systematic palaeontology of those brachiopods has already been published (Angiolini et al. 1997, 2003a; Angiolini 2001).
The specimens were embedded in resin, cut along longitudinal and transverse sections, then etched with $5 \% \mathrm{HCl}$ for $20 \mathrm{~s}$ and metallic coated before being investigated using SEM to check the preservation of their shell fabric. In addition thin sections were made to allow cathodoluminescence microscopy along the same sections.

The brachiopods were sampled for geochemical and isotope analysis by drilling $6-8 \mathrm{mg}$ along the longitudinal section of each shell using a diamond drill bit. The powder was split into two parts, one for geochemistry and $\mathrm{Sr}$ isotopes and the other for $\mathrm{C}$ and $\mathrm{O}$ isotopes. Only the diagenetically unaltered inner part of the thick secondary shell layer of both the ventral and dorsal valves was sampled for geochemical and isotope analyses (Table 1). Features such as the muscle attachment areas, articulation points, interareas and lophophore support were avoided, although Parkinson et al. (2005) showed there is a minimal risk when sampling specialised shell fragments.

Geochemical analyses were undertaken at the analytical geochemistry laboratories at the British Geological Survey and the Department of Geology, University of Leicester. Subsamples for geochemical analysis at the British Geological Survey and for $\mathrm{Sr}$ isotope analysis were dissolved in ultra-pure acetic acid. The acetic acid leached fraction reserved for geochemistry (see below) was evaporated to dryness and the residue taken up in $1 \%$ nitric acid. Geochemical data were obtained by Inductively Coupled Plasma Atomic Emission Spectroscopy (ICP-AES) on a Fison/ARL 3580 simultaneous/sequential spectrometer with Gilson auto sampler.

At the Department of Geology, University of Leicester, all the samples were digested in acetic acid and analysed using a Horiba Jobin Yvon Ultima ICP Optical Emission Spectrometer. The sample digestion was often incomplete, and residues composed of white, yellow or red material were found in some samples. A number of samples were analysed in both the British Geological Survey and University of Leicester 

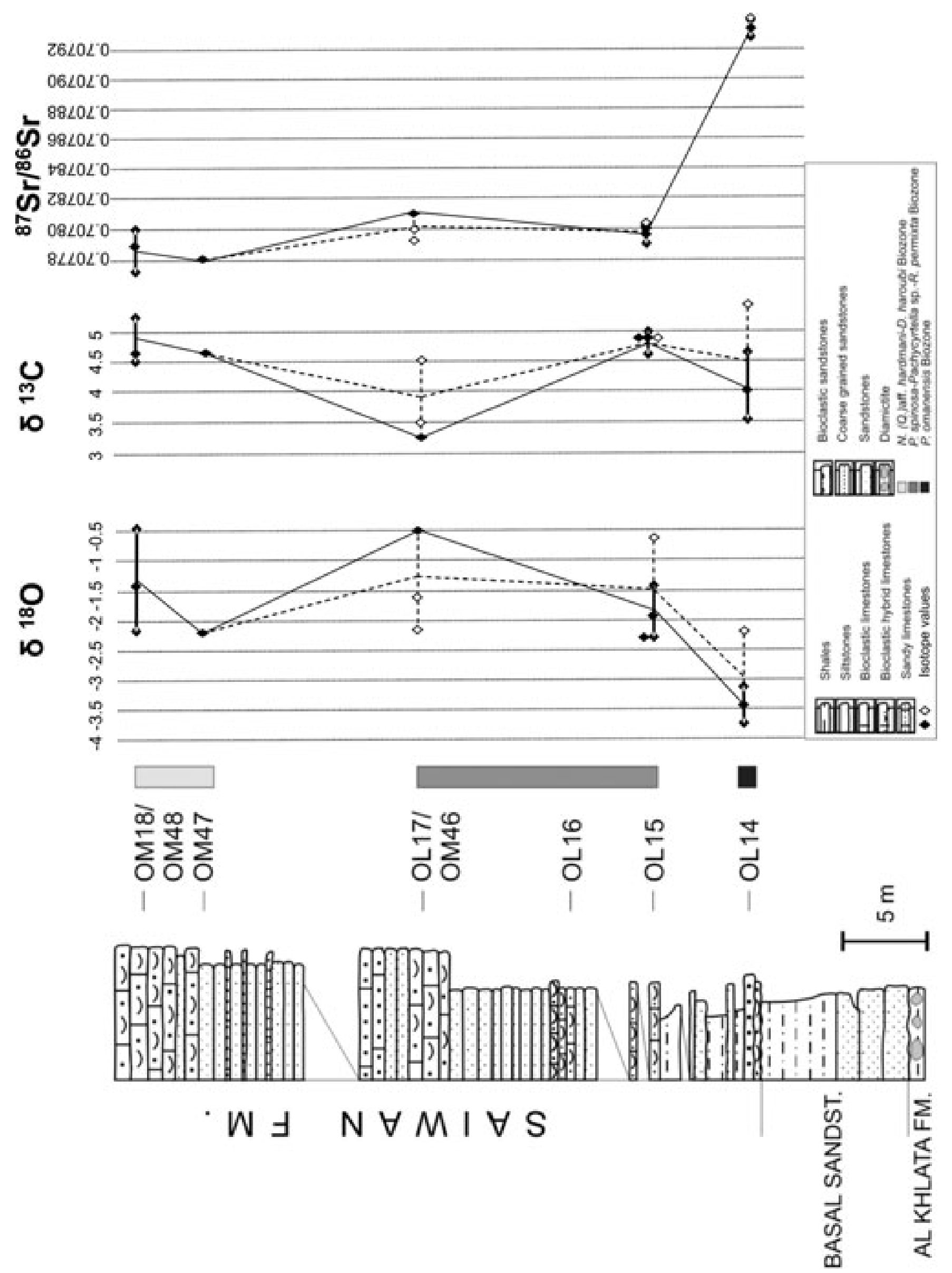
laboratories, and, given the partial dissolution that occurred for some samples, the data are consistent between the two laboratories. Although a direct one-to-one correlation is not observed between the two data sets, the positive covariance between individual elements indicates that the data sets are comparable and that any differences are the result of the partial dissolution and possible weighing errors, given the small sample sizes.

Approximately $5 \mathrm{mg}$ of the powdered carbonate was used for the carbon and oxygen isotope analysis. The sample material was reacted with anhydrous phosphoric acid in vacuo overnight at a constant $25^{\circ} \mathrm{C}$. The $\mathrm{CO}_{2}$ liberated was separated from water vapour under vacuum and collected for analysis. Measurements were made on a VG Optima mass spectrometer. Overall analytical reproducibility for these samples is normally better than $0 \cdot 1 \%$ 。 for $\delta^{13} \mathrm{C}$ and $\delta^{18} \mathrm{O}$. Isotope values $\left(\delta^{13} \mathrm{C}, \delta^{18} \mathrm{O}\right)$ are reported as per mil (\%) deviations of the isotopic ratios $\left({ }^{13} \mathrm{C} /{ }^{12} \mathrm{C},{ }^{18} \mathrm{O} /{ }^{16} \mathrm{O}\right)$ calculated to the VPDB scale using a within-run laboratory standard calibrated against NBS standards.

For $\mathrm{Sr}$ isotope analysis, a subsample of $\sim 1-3 \mathrm{mg}$ was weighed into a Savillex(C) FEP beaker and the carbonate dissolved in ultrapure $1 \mathrm{M}$ acetic acid $\left(\mathrm{CH}_{3} \mathrm{COOH}\right)$. The acetic acid solutions were centrifuged and, if the geochemical analysis was to be carried out at BGS, half of the solution retained for this purpose. The remaining solution was evaporated to dryness and the residue was taken up in $2.5 \mathrm{M} \mathrm{HCl}$. Strontium was separated by conventional cation exchange techniques using Biorad AG 50W-X8 ion exchange resin. Sr samples were loaded on rhenium ( $\mathrm{Re}$ ) filaments together with a tantalum oxide $(\mathrm{TaO})$ activator following the method of Birck (1986) and isotope ratios were measured on a Finnegan MAT Triton operated in static mode. Thirty analyses of the international strontium isotope standard NBS 987 measured on the MAT 262 during the period of study yielded a mean ${ }^{87} \mathrm{Sr} /{ }^{86} \mathrm{Sr}$ ratio of $0.710249 \pm 0.000014(2 \sigma)$. Analyses on the Triton were made at three separate times and the relevant mean values obtained for the NBS 987 international standard were $0 \cdot 710238 \pm 0.0000071(2 \sigma \mathrm{n}=21), 0 \cdot 7102414 \pm 0 \cdot 0000062(2 \sigma$ $\mathrm{n}=11)$ and $0 \cdot 7102486 \pm 0 \cdot 0000088(2 \sigma \mathrm{n}=7)$. For consistency, all the measured ratios were normalised to the accepted value of 0.710248 for NBS 987. Replicate determinations $(n=128)$ of the north Atlantic seawater standard yielded $0 \cdot 7091752 \pm 0 \cdot 0000097(2 \sigma)$.

Unless stated otherwise, the marine strontium isotope curve used to derive numerical ages is that of McArthur \& Howarth (2004). The geochronological scale used here is that of Gradstein et al. (2004).

\section{Analytical techniques to assess shell preservation}

To assess shell preservation, three screening techniques have been used: ultrastructural analysis (SEM); cathodoluminescence by a cold cathode luminoscope (Nuclide ELM2) operating at $10 \mathrm{KV}$ voltage with a current beam of 5-7 MA; and determination of trace element contents.
The SEM study of the ultrastructure is a common technique to check the preservation of shell fabric. The classification of the shell ultrastructure has been carefully described by Williams (1966, 1968, 1971), McKinnon (1974), and Williams in Williams et al. (1997). A recent paper by Samtleben et al. (2001) presents a classification of nine types of ultrastructure based on a combination of biological fabric and diagenetically altered structures. For present purposes, a classification that enhance the types of pristine shell fabric is preferred, in order to distinguish the original features of the shell from subsequent changes caused by diagenesis. Therefore, McKinnon (1974) and Williams in Williams et al. (1997) are followed for the description of the unaltered shell fabric, distinguishing specimens which show perfectly shaped or slightly imperfect and amalgamated fibres of the secondary layer from those where the secondary layer is laminar. When the shell fabric is obliterated by dissolution, amalgamation and recrystallisation the specimens are considered as diagenetically altered.

Cathodoluminescence (CL) is a screening technique widely used to assess preservation of brachiopod shells (Popp et al. 1986; Grossman et al. 1993), as they commonly show no luminescence in absence of significant geochemical alteration. However, its reliability to distinguish altered from unaltered shells has been questioned, as modern unaltered brachiopod shells can sometimes display orange-coloured luminescence typical of altered carbonate, whereas some clearly altered fossil shells can, in fact, be non-luminescent (Korte et al. 2005). England et al. (2006) have recently shown that hyperspectral CL imaging can overcome the drawbacks of conventional optical CL and determine the real causes of luminescence. They showed that the direct comparison of optical CL analyses is hampered by the fact that beam current conditions vary in the different studies. To overcome this problem of comparison between the present data, all the samples were analysed with the same instrument operating under the same beam conditions. Furthermore, CL was integrated with the other two screening techniques, cross-checking the results before discarding isotope analyses.

The third screening technique was the determination of trace element contents of $\mathrm{Ca}, \mathrm{Mg}, \mathrm{Fe}, \mathrm{Mn}$ and $\mathrm{Sr}$ in the calcite shell to assess if certain elements were in concentrations usually found in modern brachiopods. According to Brand et al. (2003) well-preserved modern brachiopods from a variety of depositional environments display $\mathrm{Sr}$ contents of 450 $1928 \mathrm{ppm}$. Mn concentrations range from 1-199 ppm with the majority of specimens containing $<80 \mathrm{ppm}$, and Fe contents are generally $<140 \mathrm{ppm}$ although values as high as $610 \mathrm{ppm}$ were observed. Popp et al. (1986) reported Sr contents as high as $3400 \mathrm{ppm}$ and $\mathrm{Mn}$ of $250 \mathrm{ppm}$ in non-luminescent portions of Palaeozoic brachiopod shells. However, the majority of their samples, which were mainly Carboniferous and Permian in age, displayed $\mathrm{Sr}$ and $\mathrm{Mn}$ concentrations within the range reported for modern brachiopods. Korte et al. (2003) adopted the criteria of $<250 \mathrm{ppm} \mathrm{Mn}$ and $>400 \mathrm{ppm} \mathrm{Sr}$ for samples to be classified as well preserved. Bruckschen et al. (1999) accepted a more conservative cut-off limit of $200 \mathrm{ppm}$ for $\mathrm{Mn}$, which they considered to be a more reliable indicator of

Figure 3 Stratigraphic log of the Saiwan Formation at the type section showing the stratigraphical position of the analysed brachiopods and their $\mathrm{O}, \mathrm{C}$ and $\mathrm{Sr}$ isotopic records. The solid symbols indicate all the values recorded by pristine carbonates for each stratigraphic level (data highlighted in bold in Table 1); multiple superimposed solid symbols indicate that the isotope values from two or more specimens from the same stratigraphic level are identical. The solid line represents the average trend. The open symbols and the dotted line represent the data from four additional specimens (OM46-9, OL17-4, OL15-66, I5-4; data underlined in Table 1) which, despite showing a diagenetically altered and luminescent shell fabric, have acceptable contents of $\mathrm{Fe}, \mathrm{Mn}$ and $\mathrm{Sr}$. 


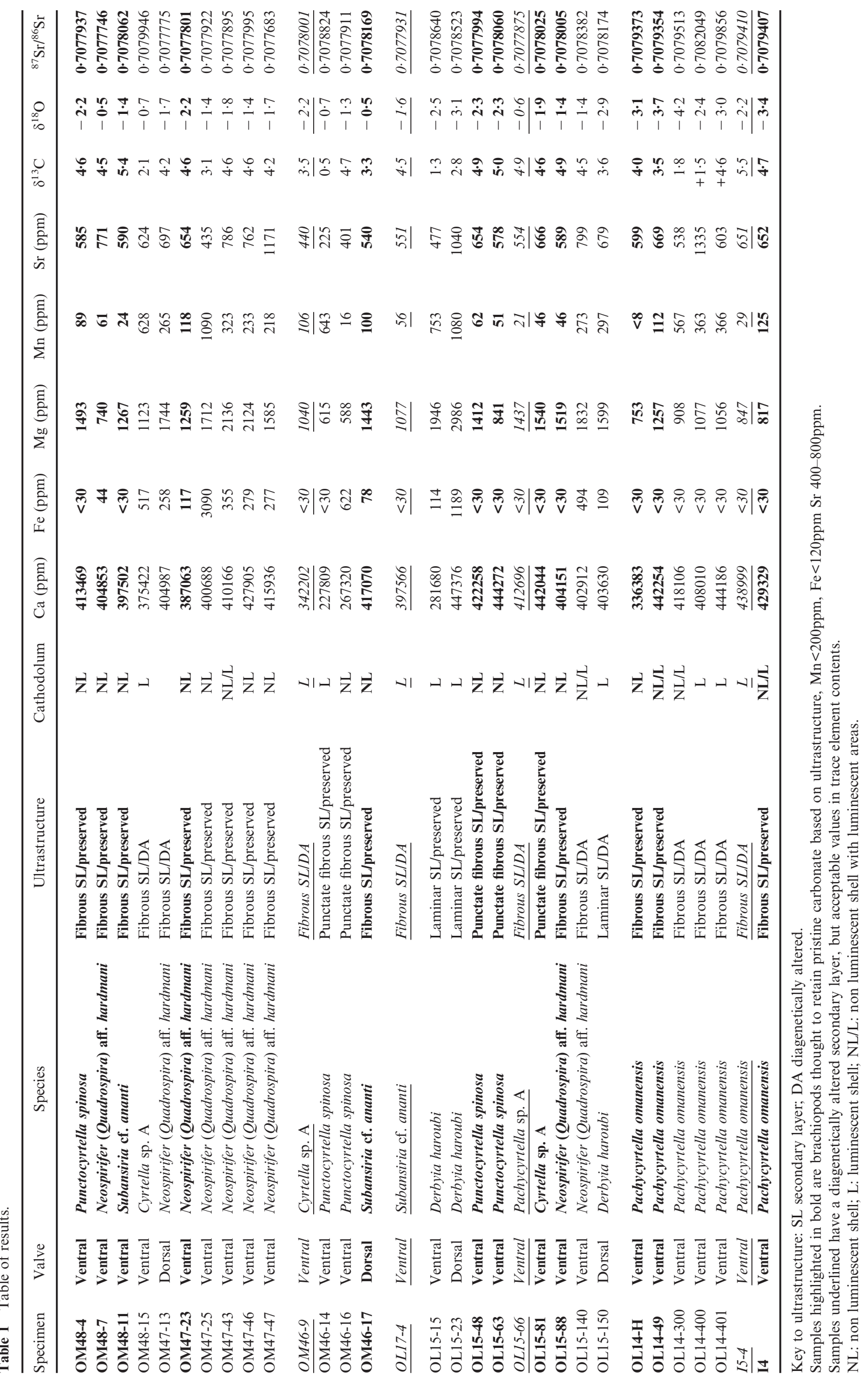


diagenetic alteration than $\mathrm{Sr}$ content. High concentrations of both $\mathrm{Mn}$ and $\mathrm{Fe}$ can result from surface coatings of oxyhydroxides, and low $\mathrm{Mn}$ and $\mathrm{Fe}$ are not always reliable indicators of pristine calcite as both elements are insoluble under oxic conditions (McArthur et al. 2000). Therefore, the Sr concentration and isotope composition of the calcite could be altered during oxic diagensis without raising the $\mathrm{Mn}$ and $\mathrm{Fe}$ contents to levels of concern. Popp et al. (1986) ascribed the variability in $\mathrm{Sr}$ concentration as mainly due to taxonomic differences among samples; however Joachimski et al. (2005) observed the highest concentrations in Silurian brachiopods (1211-1830 ppm) and much lower values (556-707 ppm) in those which were Permian in age. Steuber \& Veizer (2002) explained the trend in $\mathrm{Sr} / \mathrm{Ca}$ ratios measured in biogenic low-Mg calcite from high values observed in the Silurian to lower ratios for the Carboniferous and Permian by the change in the predominant carbonate phase from $\mathrm{Sr}$-rich calcite to Sr-rich aragonite. Joachimski et al. (2005) therefore considered that the low $\mathrm{Sr}$ concentrations in the Permian carbonates resulted from precipitation of shell calcite from seawater with low $\mathrm{Sr} / \mathrm{Ca}$ ratios rather than from a diagenetic loss of $\mathrm{Sr}$. Ca and $\mathrm{Mg}$ concentrations were analysed to establish the bulk compositions of the shells.

In the present study, limits of $200 \mathrm{ppm}$ for Mn and 400$800 \mathrm{ppm}$ for $\mathrm{Sr}$ have been adopted, and samples with $\mathrm{Fe}>120$ ppm have been excluded.

\section{Results}

\subsection{Ultrastructural analyses}

The shell structure of thirty-four specimens (OL14-1, OL16-35, OM48-14, in addition to those listed in Table 1) belonging to eight different species of articulated brachiopods (Reedoconcha permixta, Derbyia haroubi, Neospirifer (Quadrospira) aff. hardmani, Pachycyrtella omanensis, Pachycyrtella sp. A, Punctocyrtella spinosa, Cyrtella sp. A, Subansiria cf. ananti) was analysed using a SEM (Figs 4-6).

The outer primary layer is very rarely preserved and it was only clearly detected in one specimen (Fig. 5 (4)), where it shows an acicular fabric. The secondary layer is invariably present with different degrees of preservation (Table 1) and shows two kinds of fabric: (i) calcite fibres in the spiriferids and spiriferinids (Fig. $4(1-8)$, Fig. $5(1-8)$ ) as in the secondary layer of recent Terebratulida and (ii) calcitic lamination in productids and orthotetids (Fig. 6 (1-8), Fig. 7 (1)). The fabric of fibrous secondary shell is the result of the elongation of discrete patches of calcite into fibres within proteinaceous sheaths (Williams 1966, 1968, 1971; Williams in Williams et al. 1997; McKinnon 1974). Fibres tend to grow differentially forming spiral arcs with local modifications and re-orientation (Fig. 5 (6)), but remaining strongly interlocked and orthodoxly stacked (Fig. 4 (2-5), Fig. 5 (7)). The secondary layer increases in thickness from the anterior margin to the umbo, where it shows consistent variation in the orientation of the calcite fibres producing shell strengthening (Alvarez 1990). In all the investigated spire-bearing genera the transverse sections of orthodoxly stacked fibres have a keel and saddle morphology, 9-16 $\mu \mathrm{m}$ wide and $2-5 \mu \mathrm{m}$ thick (Fig. $4(1,6)$, Fig. $5(1-2,8)$ ), with Neospirifer (Quadrospira) aff. hardmani showing the largest and thickest fibres. Its shell structure is consistent with that observed by McKinnon (1974) for a Carboniferous species of Neospirifer, whose secondary orthodoxly stacked fibres measured up to $15 \mu \mathrm{m}$ in width.

In Pachycyrtella omanensis, Pachycyrtella sp. A, Punctocyrtella spinosa, Cyrtella sp. A and Subansiria cf. ananti the fibrous fabric is perforated by thin and sparse unbranched punctae $(16-27 \mu \mathrm{m}$ in diameter) around which the fibres are outwardly deflected (Fig. 5 (3, 5)), but no perforate canopies at their distal end could be detected. These spiriferinid genera are thus characterised by punctate shells with very thin and sparse punctae, whose volume is negligible when compared with the total volume of the shell. This imply that the calcitic cements filling the punctae are volumetrically negligible and do not affect the geochemical and isotopic analyses of the shells (Table 1).

The secondary fabric of the orthotetid Derbyia haroubi and of the productid Reedoconcha permixta is a cross-bladed lamination, which is well preserved in the former (Fig. $6(1-3)$ ) and strongly altered in the latter (Fig. 6 (4-8)). Laminae are about 1.5-3 $\mu \mathrm{m}$ thick in Derbyia haroubi, thus thicker than the lamination observed by Williams (1968, p. 43) in another Permian species of Derbyia. Pseudopunctae have been detected in both of these taxa, but are usually rarer and consist of rosettes of conical laminae (20-25 $\mu \mathrm{m}$ wide) in Derbyia haroubi (Fig. 6 (2)), whereas they are coarser (50 $\mu \mathrm{m}$ wide), densely distributed and with a rod of recrystallised calcite at the core (taleola) in Reedoconcha permixta (Fig. 6 (7)). Hollow spines communicating with canals to the shell interior and formed by concentric banding of flat laminae (Williams 1968) have also been detected in Reedoconcha permixta ((Fig. 6 (8)). The strongly altered secondary fabric of Reedoconcha permixta may be related to a higher organic content (proteinaceous membranes), the porous fabric of in vivo taleolae (Williams in Williams et al. 1997) and to the occurrence of hollow bases of spines, which may have favoured dissolution and recrystallisation.

A few specimens of Neospirifer (Quadrospira) aff. hardmani, Pachycyrtella omanensis and Derbyia haroubi show local traces of bioerosion (Fig. 4 (7); Fig. 6 (3)) probably caused by encrusting bryozoans and barnacles. These traces differ from the porosity caused by punctae by their larger dimensions, their branched arrangement and by the absence of deflection of the secondary layer fibres which surround them. Also they develop from the outer shell surface towards the interior, without reaching the innermost shell layer (Fig. 6 (3)). Their number, shape and arrangement (Fig. 8 (6)) indicate they are domichnial borings (Angiolini et al. 2003a) and not boreholes caused by predation, which are usually few per shell, are drilled perpendicular to shell surface and shoe site selectivity.

Based on the preservation of the secondary layer fabric, the analysed brachiopods were subdivided into two categories (Table 1): 'preserved' when all fibres/laminae of the secondary layer are intact (Fig. 4 (1-5), or when occasionally some fibres/laminae are imperfectly shaped (Fig. 4 (6), Fig. 5 (8)); or 'diagenetically altered' when the fabric is obliterated by dissolution, amalgamation and recrystallisation (Fig. $6(4,6)$; Fig. $7(3,5))$.

\subsection{Cathodoluminescence}

Following SEM analysis, CL investigation of brachiopod shells was performed using a Nuclide luminoscope (ELM28) operating at $10 \mathrm{KV}$. Neospirifer (Quadrospira) aff. hardmani, Pachycyrtella sp. A, Punctocyrtella spinosa and Subansiria cf. ananti appear mostly non luminescent with rare thin lines or bright calcite punctae infillings (Fig. $8(2,4)$ ). Generally there is good correspondence to the shell ultrastructure, with preserved specimens lacking any trace of luminescence indicating that the shells have not been affected by diagenesis (Fig. 8 (2)). When the ultrastructure indicates dissolution, amalgamation and recrystallisation of secondary layer fibres, the shell fabric is luminescent (Fig. 7 (3-6), Fig. $8(3,5))$. In some cases it is likely that luminescence, where it occurs, has been caused by diagenetic diffusion of $\mathrm{Mn}$ from the matrix to the shell through 

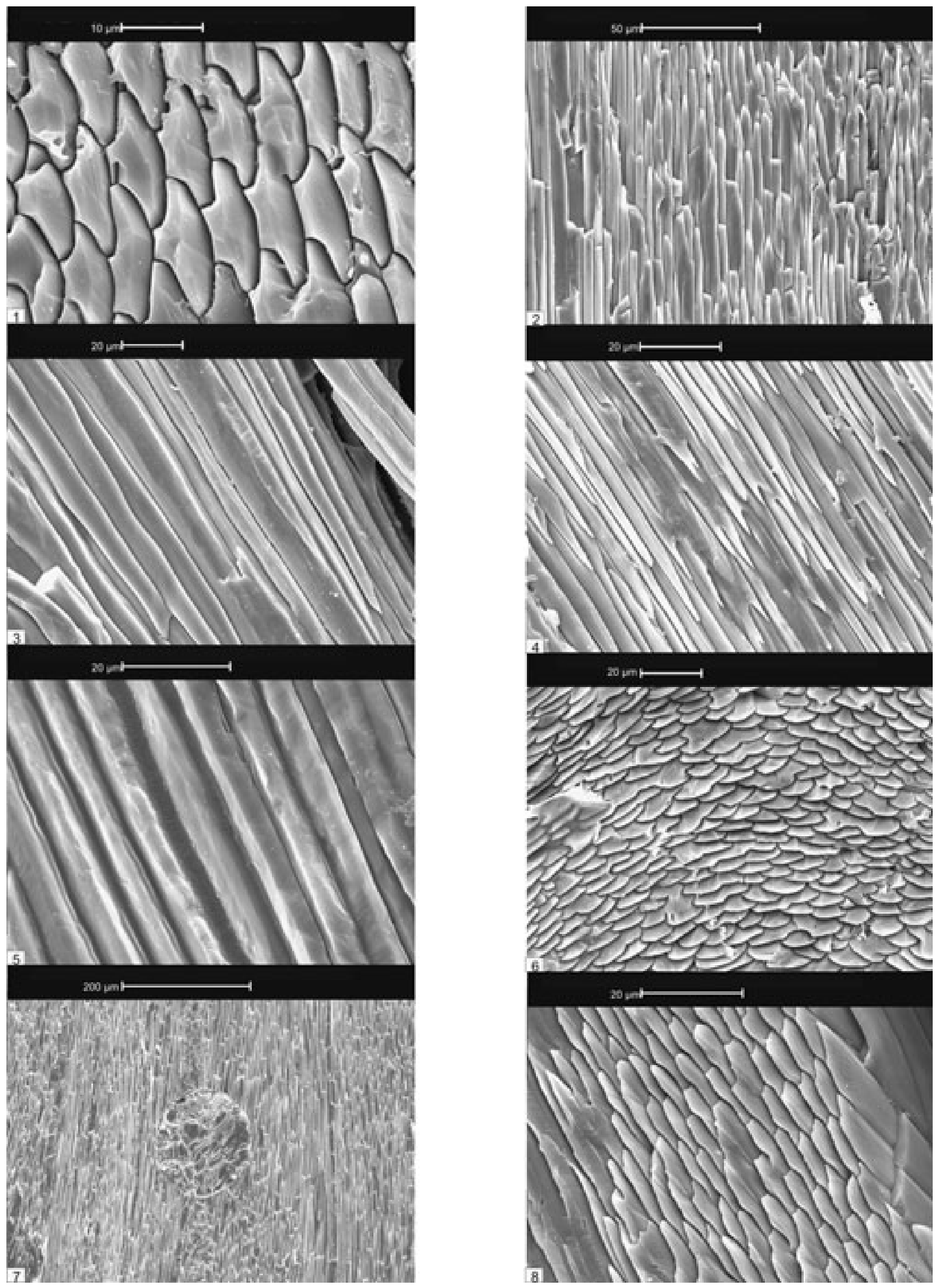
radial microfractures mainly produced by burial compaction (Fig. 7 (3-4), Fig. 8 (3)).

However there are exceptions, for example a well-preserved secondary laminar fabric, is seen in Derbyia haroubi but these specimens are also characterised by a luminescent shell (Fig. 7 (1-2), Fig. 8 (1)). This may be related to a higher organic content (proteinaceous membranes, luminescent in CL) in the original in vivo laminar fabric, whose post-mortem decomposition may cause an intra-laminar porosity. The latter in turn controlled the diffusion of Mn during diagenesis along laminar boundaries producing the pattern observed in Fig. 8 (1).

The specimens of Pachycyrtella omanensis show a very peculiar rhythmic pattern of bright CL lines, running diagonally to the shell exterior. In most cases these microstructures are periodically spaced and uniformly wide, but in some specimens they widen and grade into the surrounding non luminescent shell fabric (Fig. 7 (7-8), Fig. 8 (7)). Rhythmic CL lines are known to occur in modern brachiopods and some other marine invertebrates due to lower growth rates or growth disturbance (Barbin \& Gaspard 1995), but they have been only very recently detected in fossil brachiopods (Tomašovych \& Farkaš 2005). These authors correlated the distribution pattern of CL lines to changes in growth rates caused by short-term environmental instability suggesting that species found in stable environmental settings are more likely to have a regular repetition of CL lines, whereas species of shallower water settings have an irregular CL line patterns. This is supported by this study as we see that in some shells, the width and spacing of CL lines is more irregular and especially in Pachycyrtella omanensis which inhabited a shallow-water, physically-stressed, high-energy, environment. However, CL lines may also be related to diagenetic processes (Tomašovych \& Farkaš 2005) and there is not enough data to solve this uncertainty. What is certain is that widening of $\mathrm{CL}$ lines into irregular fringed banding is due to diagenetic diffusion (Fig. 8 (7)).

The relationships between preservation and luminescence can be interpreted taking into account the characteristic of the bulk rock, which is generally characterised by different orange colours recording the major diagenetic events. Most of the bioclasts (bivalves, gastropods, echinoderms, bryozoans) and coated grains are predominantly orange (Fig. 8 (8)), whereas the pristine fibrous secondary layer of brachiopods is usually black. CL analysis of microfacies suggests that diagenesis did not significantly affect the resistant original fibrous fabric of the brachiopod shells.

\subsection{Elemental data}

As stated in section 3, a limit of 200 ppm for Mn had been adopted in this study and samples with $\mathrm{Fe}>120 \mathrm{ppm}$ have been excluded. Not all the samples with high levels of Mn have elevated Fe contents (Table 1) and in the case of OM46-16, high $\mathrm{Fe}$ is accompanied by very low $\mathrm{Mn}$. Also, whilst some samples which exhibit diagenetic alteration have high Mn and $\mathrm{Fe}$, some have contents which would be deemed acceptable (OM46-9, OL17-4, OL15-66; I5-4).
Sr concentrations in the analysed brachiopods range from 225 to $1335 \mathrm{ppm}$ (Table 1), however all of the specimens with $\mathrm{Sr}<500 \mathrm{ppm}$ display other indicators of poor preservation. Three samples have much higher concentrations than the norm and $\mathrm{Mn}$ and $\mathrm{Fe}$ above the adopted cut-off levels. Sr levels generally decrease during diagenetic alteration of low-Mg calcite; however if the fluid responsible for the alteration was $\mathrm{Sr}$ rich, then increased concentrations might be observed. Celestite occurrences are reported from the top of the $\mathrm{Al}$ Khlata Formation and in the clastic basal deposits of the Saiwan Formation (Angiolini et al. 2003a, Le Métour et al. 1994), possibly indicating migration of supersaline brines during diagenesis.

$\mathrm{Sr} / \mathrm{Ca}$ ratios of the pristine brachiopods range from 0.60 to $0.87 \mathrm{mmol} / \mathrm{mol}$ and a $\mathrm{Sr} / \mathrm{Ca}$ ratio for seawater may be calculated assuming a value for the molar distribution coefficient for Sr of $0 \cdot 13\left[\mathrm{D}_{\mathrm{Sr}}=\left(\mathrm{M}_{\mathrm{Sr}} / \mathrm{M}_{\mathrm{Ca}}\right)_{\text {carbonate }} /\left(\mathrm{M}_{\mathrm{Sr}} / \mathrm{M}_{\mathrm{Ca}}\right)_{\text {seawater }}\right]$ as observed in modern brachiopods (Steuber \& Veizer 2002). The resultant mean ratio of $5.35 \pm 0.64 \mathrm{mmol} / \mathrm{mol}$ is comparable with values calculated by Steuber \& Veizer (2002) for the Early Permian seas.

Interestingly, brachiopods with laminar secondary layer show trace element contents outside the acceptable values even when the ultrastructure is very well preserved (D. haroubi in OL15). This is in agreement with the data of Parkinson et al. (2005), who showed that extant brachiopods with laminar ultrastructure (i.e. craniids) do not record ambient seawater composition and are not recommended as climate proxies.

Brachiopods thought to retain pristine carbonate based on ultrastructure, CL and trace elements are highlighted in bold in Table 1. Their isotopes values have been used to construct the solid curves in Figure 3. However, there are four additional specimens (OM46-9, OL17-4, OL15-66, I5-4; underlined in Table 1) which despite showing a diagenetically altered and luminescent shell fabric have acceptable contents of $\mathrm{Fe}, \mathrm{Mn}$ and $\mathrm{Sr}$. Those have been added using a dotted line in Figure 3 and are discussed in the following sections.

\subsection{Stable isotope data}

Carbon and oxygen data from 31 brachiopod shells which were analysed for stable isotopes range between +0.5 and $+5.5 \%$ and $-4 \cdot 2$ to $-0.5 \%$ o respectively. The lower $\delta^{13} \mathrm{C}$ occur in samples where there is other evidence for alteration. However, on the whole, the stable isotope data do not provide supporting evidence for alteration. The brachiopods which are thought to be comprised of pristine carbonate (samples highlighted in bold, Table 1) have $\delta^{13} \mathrm{C}$ between $+3 \cdot 3$ to $+5 \cdot 4 \%$ o and $\delta^{18} \mathrm{O}-3 \cdot 7$ to $-0.5 \%$. The oxygen isotope data lies within the range that is generally thought to represent Permian seawater values (Korte et al. 2005).

When plotted stratigraphically (solid symbols in Fig. 3), the pristine brachiopods show the lowest $\delta^{18} \mathrm{O}$ in the oldest specimens (OL 14, $n=3)$, increasing values in OL15 $(n=4)$ and the highest values in OL46 $(n=1)$, before a decrease in OM47 $(\mathrm{n}=1)$. The youngest samples (OM48) have the most variable $\delta^{18} \mathrm{O}$ but all individuals $(\mathrm{n}=3)$ have $\delta^{18} \mathrm{O}$ that is higher than

Figure 4 Ultrastructure of Neospirifer (Quadrospira) aff. Hardmani: (1) Transverse section of well-preserved secondary layer fibres with keel and saddle outline, specimen OM48-7, ventral valve; (2) Longitudinal section of well-preserved orthodoxly stacked secondary layer fibres, specimen OM48-14, ventral valve; (3) Longitudinal section of well-preserved orthodoxly stacked secondary layer fibres, specimen OM47-47, ventral valve; (4) Spatulate termination of well-preserved orthodoxly stacked secondary layer fibres, specimen OM47-47, ventral valve; (5) Longitudinal section of well-preserved orthodoxly stacked secondary layer fibres, specimen OL15-88, ventral valve; (6) Transverse section of secondary layer showing some imperfectly shaped fibres (arrows), specimen OM47-43, ventral valve; (7) Longitudinal section of orthodoxly stacked secondary layer fibres, showing a trace of bioerosion filled by calcite cements, specimen OM48-14, ventral valve; (8) Oblique section of secondary layer showing some imperfectly shaped fibres, specimen OM47-46, ventral valve. 

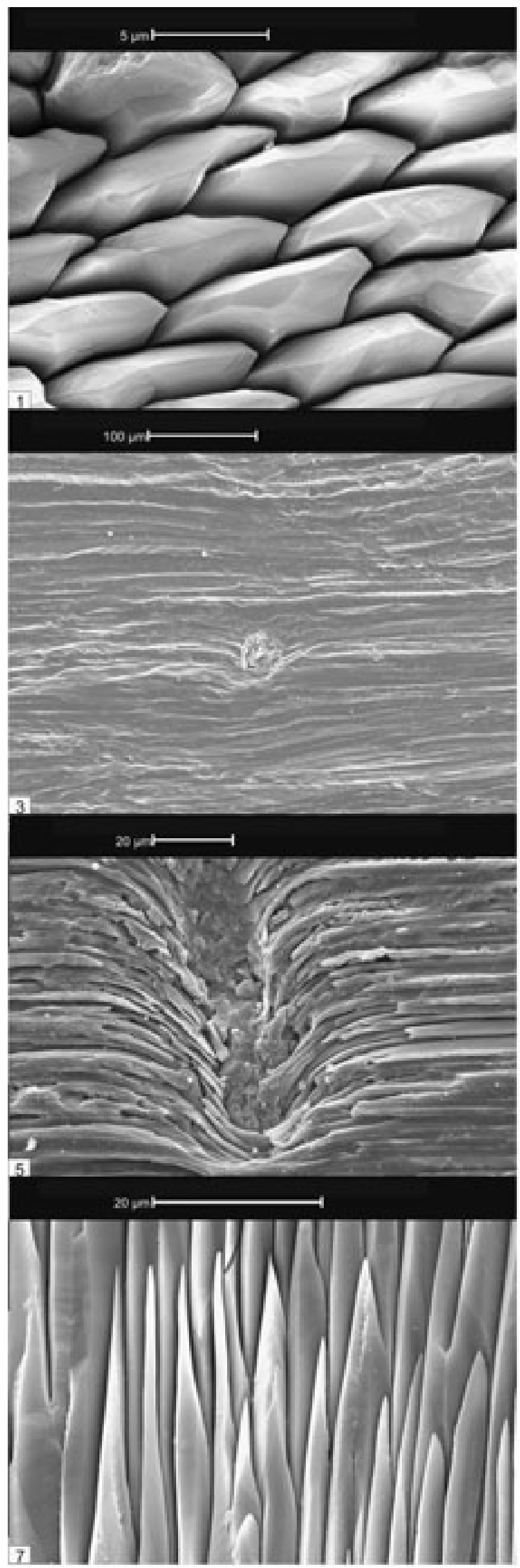
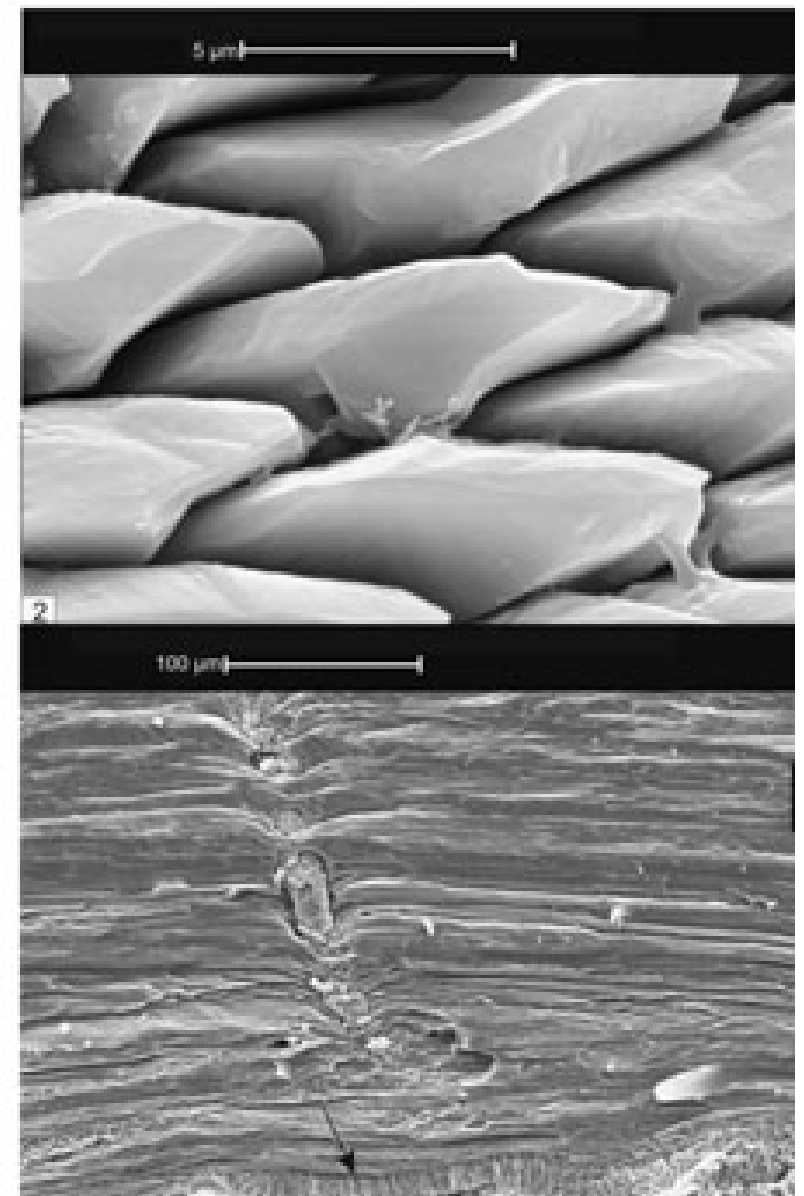

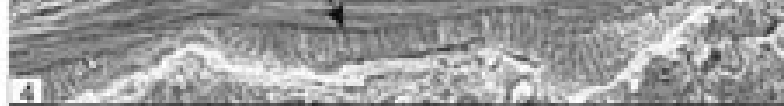

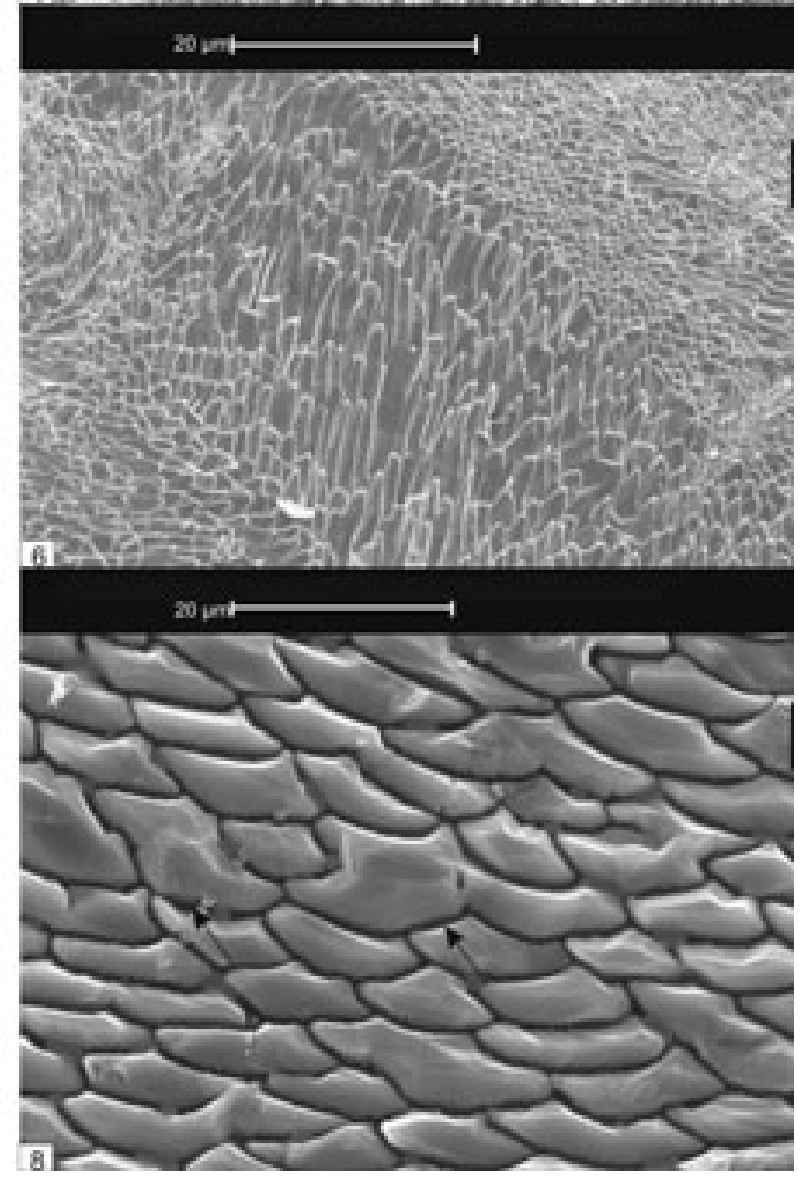


the lowermost OL14. Plotting also the values of the four additional specimens which show a diagenetically altered and luminescent shell fabric, but have acceptable contents of $\mathrm{Fe}$, $\mathrm{Mn}$ and $\mathrm{Sr}$ (samples underlined in Table 1 and represented by open symbols in Fig. 3), results in a very similar trend which is slightly smoothed especially in correspondence of the decrease in OM47. Data from the stratigraphic level OL14 are derived from the use of the single species $P$. omanensis, whereas the results from the overlying stratigraphic beds are obtained using a combination of different species $(N .(Q$.) aff. hardmani, Cyrtella sp. A, Pachycyrtella sp. A, P. spinosa, S. ananti): this could imply a taxonomic control on the trend. However, Parkinson et al. (2005) found no significant difference in $\delta^{18} \mathrm{O}$ values from the secondary layer of four terebratulid and one rhynchonellid co-existing species, thus excluding a taxonomic control on brachiopods with this standard ultrastructure. Also the species Pachycyrtella omanensis may be restricted to bed OL14, but the genus Pachycyrtella ranges higher, and in bed OL15 it shows similar isotopic values to the co-existing $N$. (Q.) aff. hardmani and Cyrtella sp. A, but very different values from the ones recorded in OL14 (Table 1).

The down section range in $\delta^{13} \mathrm{C}$ (Fig. 3) is almost the same as the within stratigraphical level range with the exception of OM46-17, where the lowest $\delta^{13} \mathrm{C}$ corresponds with the highest $\delta^{18} \mathrm{O}$. This variation is less evident if the values of the four additional specimens OM46-9, OL17-4, OL15-66, I5-4 are added (dotted line in Fig. 3). However, carbon stable isotope composition of brachiopods may be affected by metabolism, so that this variation may be not indicative of an environmental change.

\subsection{Strontium isotope data}

The strontium isotope ratios of brachiopod specimens from bed OL14 are significantly higher than those from higher levels in the sequence. The three samples considered to be pristine (highlighted in bold in Table 1) yield a mean ${ }^{87} \mathrm{Sr} /{ }^{86} \mathrm{Sr}$ ratio of $0.7079378 \pm 0.0000054(2 \sigma)$ and all of the less well-preserved samples have higher ratios. Sample OL14-400 has a $\mathrm{Sr}$ isotope composition which approaches that obtained for a sample of celestite from the base of the Saiwan Formation (0.7082904: D. P. F. Darbyshire, unpublished data) suggesting that it might be the source of the elevated $\mathrm{Sr}$ concentration. The mean ratio for the four pristine specimens from level OL15 is $0 \cdot 7078021 \pm 0 \cdot 0000058(2 \sigma)$, and with the exception of OL1566 , the altered samples display higher ratios. However, specimen OL15-23 with a Sr concentration of $1040 \mathrm{ppm}$ did not have the highest $\mathrm{Sr}$ isotope signature. Only one of the brachiopods from bed OL17/OM46 passed all the selection criteria for good preservation (OM46-17 $\left.{ }^{87} \mathrm{Sr} /{ }^{86} \mathrm{Sr}=0.7078169\right)$; surprisingly the mean ratio for all five samples is almost identical $(0 \cdot 7078167 \pm 0 \cdot 0000762)$, but the large error reflects the range in values. The values obtained by the two additional specimens OM46-9 and OL17-4 are very close to the value obtained by the only one of the brachiopods which passed all the selection criteria for good preservation (Fig. 3). Similarly, in the over- lying bed, only one sample was found to be pristine (OM47-23) and its $\mathrm{Sr}$ isotope signature $(0 \cdot 7077801)$ is close to the average value for all six specimens $(0 \cdot 7077845 \pm 0 \cdot 0000226)$. The best estimate of the external precision of a single measurement is given by the standard deviation of 128 analyses of north Atlantic seawater $( \pm 0.00000962 \sigma)$ over a 2 -year period. So while the $\mathrm{Sr}$ isotope signatures of pristine brachiopods in beds OL15 and OL17/OM46 overlap within analytical error, a significant decrease in ratio is observed in bed OM47. The three well-preserved brachiopod specimens from OM48 display the widest range of ${ }^{87} \mathrm{Sr} /{ }^{86} \mathrm{Sr}$ ratios and the mean value is $0 \cdot 7077915 \pm 0 \cdot 0000318(2 \sigma)$. Variations of up to $50 \times 10^{-6}$ have been observed in pristine brachiopods within the same stratigraphical level (e.g. Azmy et al. 1999). The diagenetically altered specimen (OM48-15) from this bed yielded a significantly higher ratio although the $\mathrm{Sr}$ content appeared to be unaffected lending credence to the suggestion that dense punctae may have diagenetically altered fillings.

\section{Interpretation and discussion}

There are relatively few studies using stable isotopes specific to the Early Permian. There are, however, low resolution isotope curves which record seawater composition for most of the Phanerozoic based on compilations of the carbon and oxygen isotope ratios of brachiopod shells (e.g. Veizer et al. 1999). Through the Phanerozoic, changes in marine $\delta^{13} \mathrm{C}$ are interpreted in terms of global changes in burial and re-oxidation of organic matter, although other processes such as release of low $\delta^{13} \mathrm{C}$ volcanic or mantle $\mathrm{CO}_{2}$ into the atmosphere, discharges of oceanic methane and overturn of low $\delta^{13} \mathrm{C}$ anoxic bottom waters are all described (Korte et al. 2005). A recent study by Pufahl et al. (2006) on Miocene brachiopods from an epeiric sea (South Australia) shows that higher $\delta^{13} \mathrm{C}$ may be related to increased aridification and decreasing continent derived nutrients. Variation in $\delta^{18} \mathrm{O}$ in brachiopod shells is thought to be largely due to the growth and retreat of continental glaciers (e.g. Veizer et al. 1997). The Phanerozoic seawater curves show that in the Early Permian there was a rapid decline in $\delta^{18} \mathrm{O}$, although the $\delta^{13} \mathrm{C}$ curve is rather flat (Veizer et al. 1999).

The only specific Permian isotope seawater curves are based on a compilation of brachiopod data from a series of discrete basins (Korte et al. 2005). This $\delta^{18} \mathrm{O}$ data shows a decline of $2.5 \%$ in the Early Permian (Asselian to Artinskian) (Korte et al. 2005, fig. 8). The main cause of the decline, which reached a minimum in the Artinskian (Korte et al. 2005), was the return of ${ }^{18} \mathrm{O}$-depleted glacial meltwater to the oceans after melting of Carboniferous-Permian glaciers at high latitudes. Closer inspection of Korte's data set published online (doi: $10.1016 /$ j.palaeo.2005.03.015) shows that this decline is not as smooth as the compiled data, notable is an excursion to higher $\delta^{18} \mathrm{O}$ values, within the overall trend towards lower values, in the Sakmarian. The Early Permian brachiopod data given in Korte et al. (2005) are entirely derived from the Southern Urals (sections from Usolka, Sakmara and Dalnij Tyulkas,

Figure 5 Ultrastructure of Pachycyrtella omanensis (1-4), Pachycyrtella sp. A (5), Subansiria cf. ananti (6), Punctocyrtella spinosa (7-8): (1) Transverse section of well-preserved secondary layer fibres with keel and saddle outline, specimen OL14-49, ventral valve; (2) Transverse section of well-preserved secondary layer fibres with keel and saddle outline, specimen OL14-49, ventral valve; (3) Longitudinal section of well-preserved orthodoxly stacked secondary layer fibres showing a transverse section of a punctum, specimen I4, ventral valve; (4) Longitudinal section of well-preserved primary (arrow) and secondary layers showing a longitudinal section of a punctum, specimen OL14-1, ventral valve; (5) Longitudinal section of well-preserved orthodoxly stacked secondary layer fibres showing a longitudinal section of a punctum, specimen OL15-66, ventral valve; (6) Local modification and re-orientation in the growth of secondary layer fibres, specimen OM48-11, ventral valve; (7) Spatulate termination of well-preserved orthodoxly stacked secondary layer fibres, specimen OL15-48, ventral valve; (8) Transverse section of secondary layer showing some imperfectly shaped fibres (arrows), specimen OL15-63, ventral valve. 

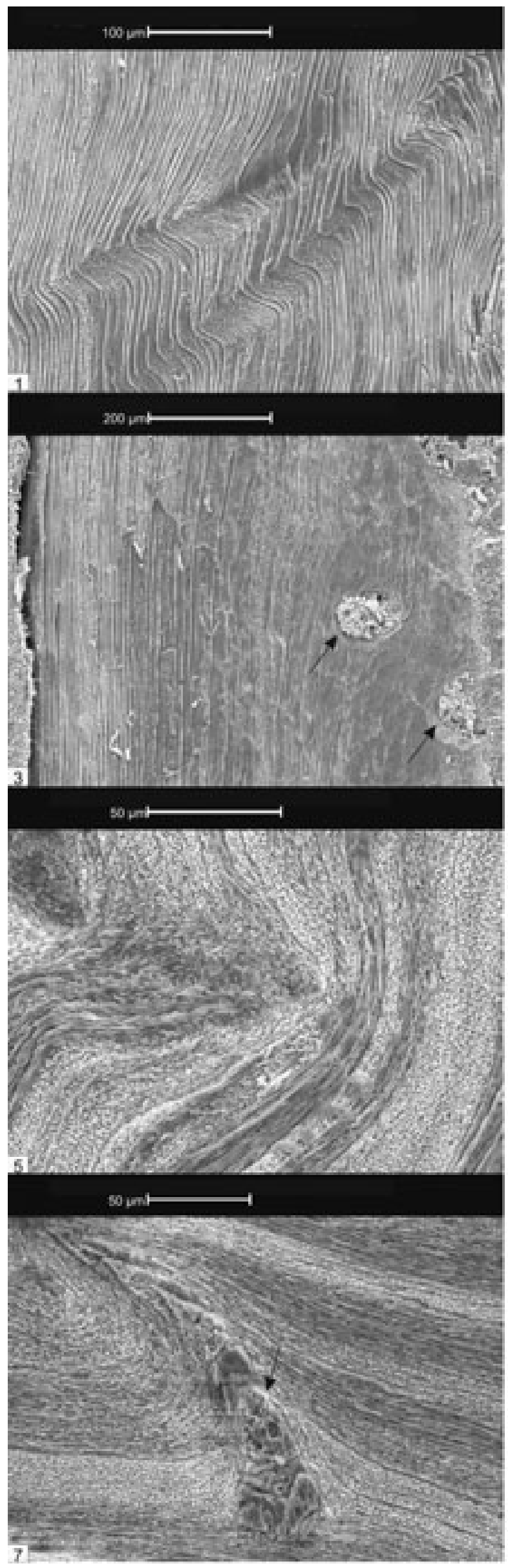

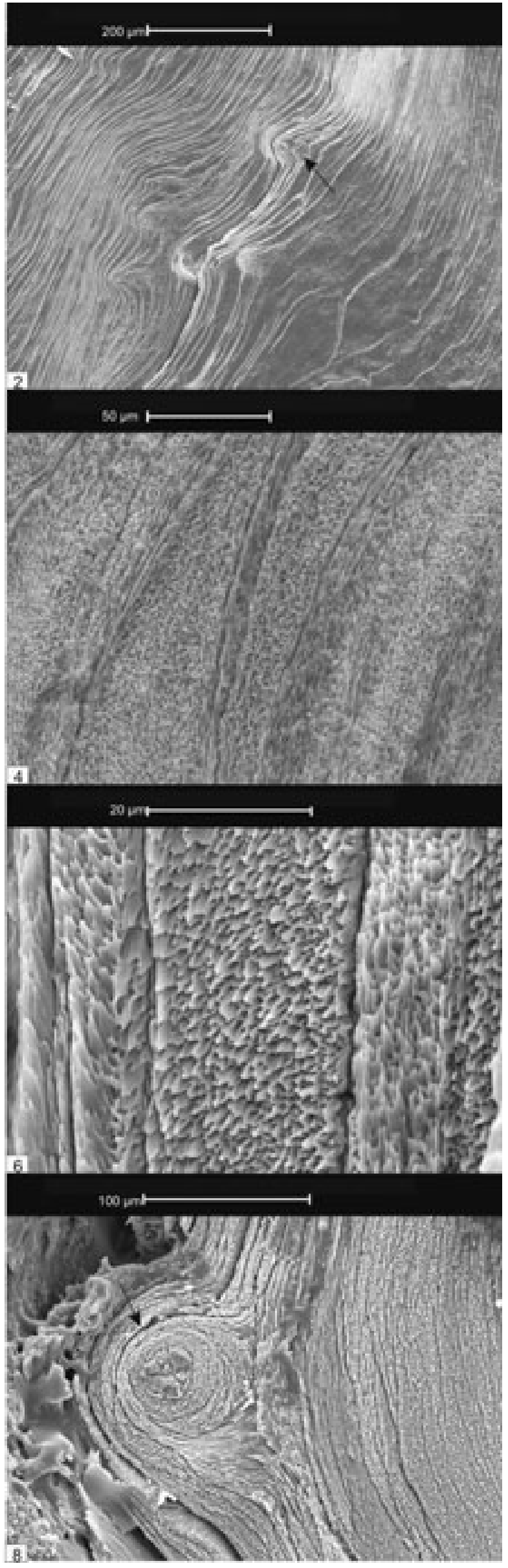


described in Chuvashov et al. 1990, 1991, 2002 (references in Korte et al. 2005)). The Southern Urals were palaeo-equatorial at this time, and brachiopods are thought to have lived in basins that were open to the Palaeotethys Ocean. In general, the compilation of data given in Korte et al. (2005) shows that $\delta^{13} \mathrm{C}$ values in the Early Permian were stable around $+4 \cdot 3 \%$.

High-resolution isotopic data from the late Sakmarian Saiwan Formation show that $\delta^{13} \mathrm{C}$ varies between $+3 \cdot 3$ and $+4.7 \%$, which is consistent with the data of Korte et al. (2005). However, there is an increase in $\delta^{18} \mathrm{O}$ from basal values of $-3 \cdot 7$ to $-3 \cdot 1 \%$ to a high of $-0.5 \%$, conflicting with the smoothed data of Korte et al. (2005), though it may be equivalent to a similar increase seen in Korte's unsmoothed data.

Excluding a species-dependent effect (see section 4.4), the basal low $\delta^{18} \mathrm{O}$ values $(-3.7$ to $-3 \cdot 1 \%$ o) from OL14 are probably related to an influx of ${ }^{18} \mathrm{O}$-depleted glacial melt water. This is supported by the presence of the Pachycyrtella palaeocommunity, a cold-water opportunistic fauna that is the first recorded above glacigene sediments in the Oman succession. There are two explanations for the subsequent $\delta^{18} \mathrm{O}$ increase through the Saiwan Formation. The increase could be related to ice accumulation. Though the Oman succession shows no glacigene sediments above the Rahab Shale (Stephenson et al. 2005), there is evidence for glacial conditions, in the form of lonestones, within late SakmarianArtinskian sediments in eastern Australia and Tasmania (Banks \& Clarke 1987; Frank et al. 2005; Fielding et al. 2005; Dickins 1996; Martini \& Banks 1989) and also from biotic records in eastern Australia during the latest Sakmarian (see Stephenson et al. in press). However, except for localised ice-centres and the presence of seasonal rafting ice, there is no evidence for a regionally continental-scale ice accumulation in Eastern Gondwana after the early Permian (G. Shi, written comm.).

There is thus a second explanation for the observed $\delta^{18} \mathrm{O}$ values in the Saiwan Formation above OL14. Increasing $\delta^{18} \mathrm{O}$ would occur in a marine basin where high evaporation causes seawater $\delta^{18} \mathrm{O}$ (and subsequently $\delta^{18} \mathrm{O}$ in the brachiopods) to rise, and this commonly occurs with little impact on seawater salinity and thus on the distribution of ecological niches. Surface and subsurface facies and geological evidence shows that the Saiwan Formation/Lower Gharif member was deposited in an embayment south of the Oman Mountains (Fig. 2). The area, now occupied by the Oman Mountains, was a rising rift shoulder in the Sakmarian related to the opening of the Neotethys Ocean (Angiolini et al. 2003a, b) which probably limited circulation between the Haushi Sea and the
Neotethys Ocean. In addition, postglacial warming, increasing aridity and northward drift of Arabia and Gondwana during this interval (Angiolini et al. 2003b, Stephenson et al. 2005) would contribute to higher evaporation. A similar scenario was envisaged for the Delaware Basin (Guadalupe Mountains), where brachiopods were found to have high $\delta^{18} \mathrm{O}$ in the Kungurian and Guadalupian (Korte et al. 2005). The general trend towards slightly heavier $\delta^{13} \mathrm{C}$ supports not only increasing aridity, but also decreasing nutrients, as shown for the epeiric Murray Basin in the Miocene by Pufahl et al. (2006).

The LOWESS ${ }^{87} \mathrm{Sr} /{ }^{86} \mathrm{Sr}$ curve of McArthur \& Howarth (2004) is relatively flat for Asselian and Sakmarian seawater with values around 0.7081 , but at the beginning of the Artinskian there is a steep decline in the ratio to $0 \cdot 7075$. The seawater curve for the Cisuralian is based on data from Denison et al. (1994a) and Martin \& McDougall (1995) and is defined by a relatively small number of data points, particularly in the Sakmarian. Denison et al. (1994a) measured isotope ratios of lime mudstones and wackestones from the USA whereas Martin \& McDougall (1995) analysed conodonts from the USA and Pakistan. Denison et al. (1994a, b) considered that as limemud-supported rocks excluded foreign pore fluids more effectively, they were more likely to retain the original seawater isotope composition. They adopted a rejection criterion of $\mathrm{Sr} / \mathrm{Mn}>2$ and $\mathrm{Mn}<300 \mathrm{ppm}$; however McArthur \& Howarth (2004) used only some of the data from this suite of samples.

There is some evidence (Ebneth et al. 2001) that conodonts yield more radiogenic signatures than brachiopods of comparable age because they are susceptible to isotopic exchange with the surrounding matrix. However, Martin \& McDougall (1995) focused on the time interval from middle Permian (Kungurian) to early Triassic, so there is no overlap with the samples measured here.

All of the pristine brachiopods analysed in this study display $\mathrm{Sr}$ isotope signatures that are less radiogenic than indicated by the LOWESS seawater curve (McArthur \& Howarth 2004) for the Sakmarian. It might be argued that given the proximal environment postulated for the surface Saiwan Formation (Angiolini et al. 2006), the seawater would be more likely to have a terrigenous contribution. However, this component would have an even lower $\mathrm{Sr}$ isotope ratio, which tends to rule out sedimentary sources. Volcanic lithics are abundant in the upper part of the Al Khlata Formation and granitoid rock fragments are common. However, the Pachycyrtella Bed at the base of the Saiwan Formation is arkosic in composition, with a reduction in the amount of quartz indicating widespread exposure of granitoid to gneissic basement (Angiolini et al.

Figure 6 Ultrastructure of Derbyia haroubi (1-3) and Reedoconcha permixta (4-8): (1) Well-preserved secondary layer lamination, specimen OL15-23, dorsal valve; (2) Calcitic cross-bladed lamination showing pseudopunctation in the form of rosettes of conical laminae (arrow), specimen OL15-23, dorsal valve; (3) Well-preserved secondary layer lamination showing two traces of bioerosion (arrows), specimen OL15-15, ventral valve; (4) Calcitic cross-bladed lamination strongly affected by diagenetic alteration, specimen OL16-35, ventral valve; (5) Calcitic cross-bladed lamination strongly deflected by pseudopunctation, specimen OL16-35, ventral valve; (6) Calcitic cross-bladed lamination strongly affected by diagenetic alteration, specimen OL16-35, ventral valve; (7) Pseudopunctum with taleola, a rod of recrystallised calcite at the core (arrow), specimen OL16-35, ventral valve; (8) Section of the base of a hollow spine (arrow), showing concentric banding, specimen OL16-35, ventral valve.

Figure 7 SEM and petrological microscope photographs of specimens showed in the left column of Figure 8: (1) SEM laminar fabric, Derbyia haroubi, specimen OL15-23, dorsal valve; (2) Petrological microscope photograph in transmitted light, Derbyia haroubi, specimen OL15-23, dorsal valve; (3) SEM recrystallised fabric, Neospirifer (Quadrospira) aff. hardmani, specimen OL15-140, ventral valve; (4) Petrological microscope photograph in transmitted light, Neospirifer (Quadrospira) aff. hardmani, specimen OL15-140, ventral valve; (5) SEM shell fabric showing diagenetic alteration (left), Cyrtella sp. A, specimen OM48-15, ventral valve; (6) Petrological microscope photograph in transmitted light, Cyrtella sp. A, specimen OM48-15, ventral valve; (7) SEM shell fabric showing diagenetic alteration, Pachycyrtella omanensis, specimen OL14-401, ventral valve; (8) Petrological microscope photograph, Pachycyrtella omanensis, specimen OL14-401, ventral valve. 

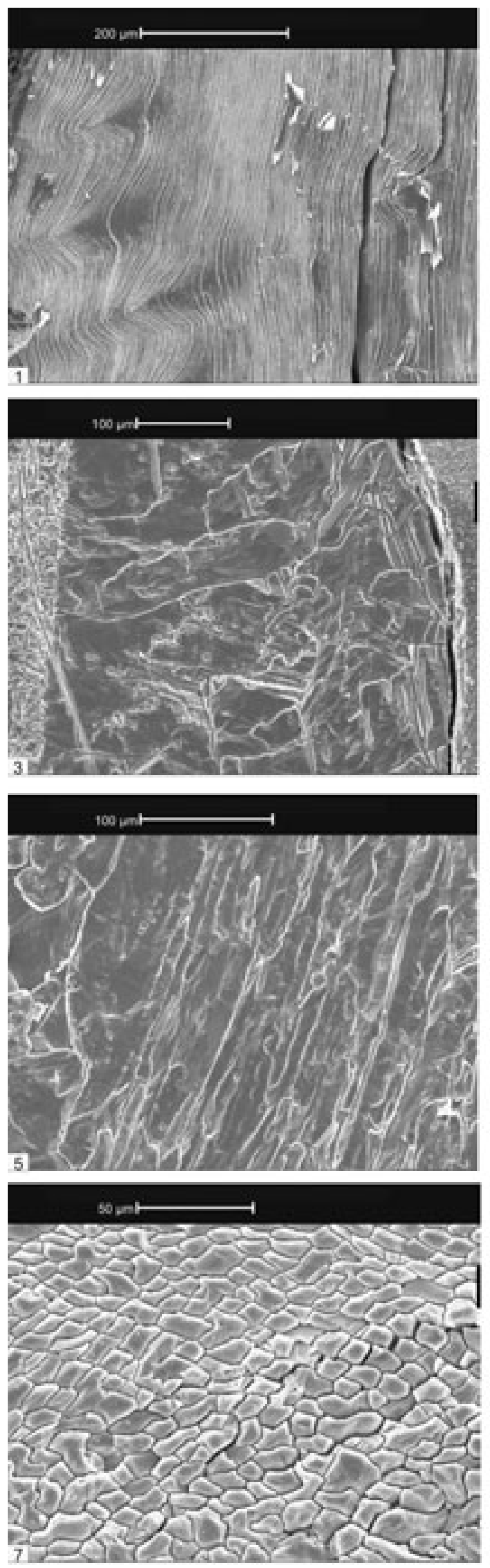

Figure 7
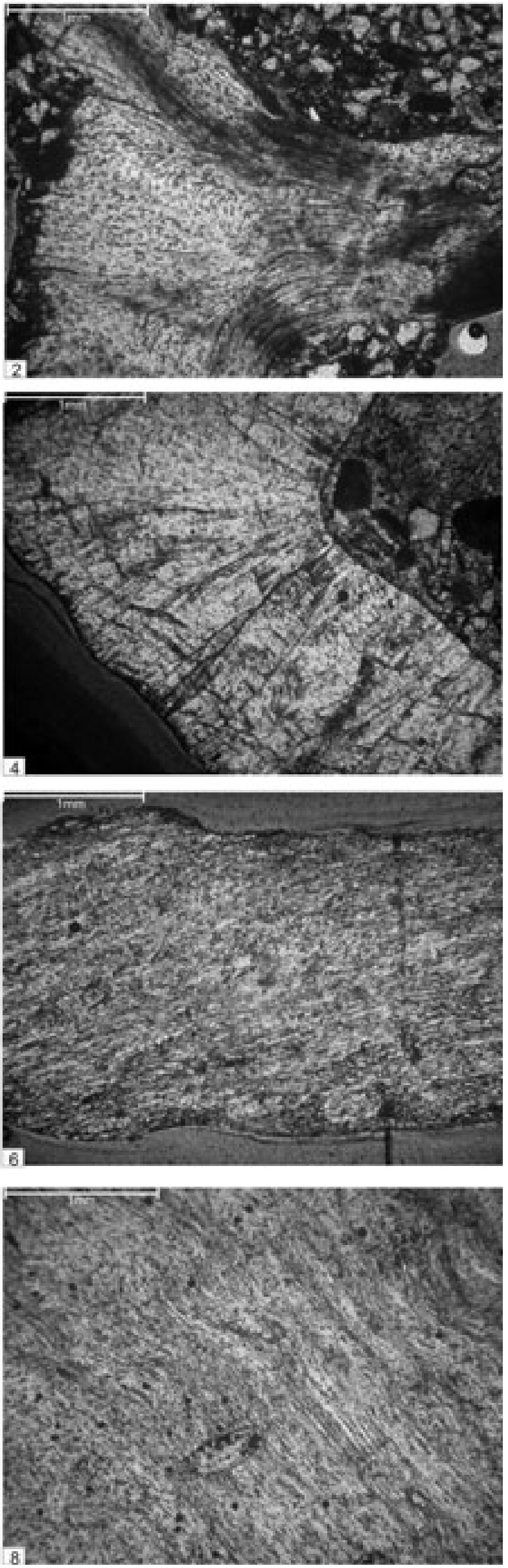

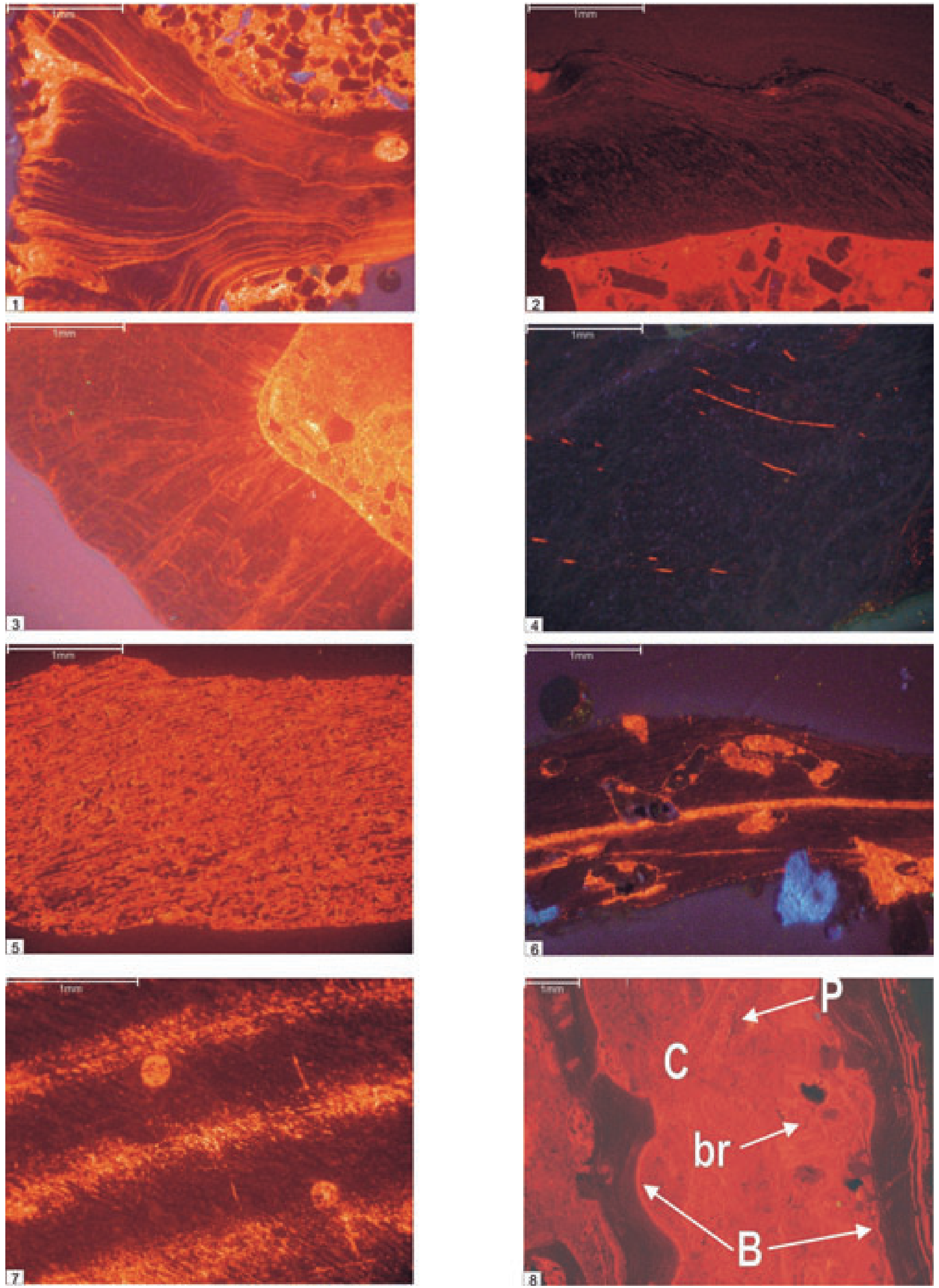

Figure 8 Caption overleaf. 
2003a). Rivers draining these rocks are less likely to acquire a low $\mathrm{Sr}$ isotope signature. It is therefore more plausible to suggest that the pristine brachiopods analysed in this study are recording the late Sakmarian seawater signature in the region. The $\mathrm{Sr} / \mathrm{Ca}$ ratios are typical of the Early Permian seas elsewhere (Steuber \& Veizer 2002) and preliminary data for brachiopods from the equivalent beds in the subsurface Haushi limestone (Angiolini et al., unpublished data) indicate similar or slightly more negative $\mathrm{Sr}$ isotope ratios. The brachiopod assemblage in the subsurface Haushi limestone is consistent with a deeper marine environment, more distant from the source of terrigenous input. If the ${ }^{87} \mathrm{Sr} /{ }^{86} \mathrm{Sr}$ ratios of the brachiopods from the surface Saiwan Formation reflected a riverine contribution to the seawater at the basin margin, then we might expect to find higher ratios in those from the deeper waters of the basin, but this was not observed.

\section{Conclusions}

The Lower Permian (Sakmarian) succession of the Haushi basin, Interior Oman (Saiwan Formation/lower Gharif member) records rapid climate change through glacial conditions to subtropical desert. This was caused by global warming following the Permo-Carboniferous glaciation, enhanced by northward continental drift during the Early Permian. Palynological, $\delta^{13} \mathrm{C}_{\text {org }}$ and organic geochemical studies (Stephenson et al. 2005) show palaeoenvironmental change through the lower part of the succession in south Oman. The isotope record may have resulted from climate amelioration through increases in palaeoatmospheric $\mathrm{CO}_{2}$. Studies of similar beds at outcrop show changes in the fauna including the development of a pioneer cold-water brachiopod community (OL14), followed by a more mature secondary ecological community of a more diversified marine biota (OL15-OL18), indicating significant climatic amelioration and concomitant decrease in nutrient availability (Angiolini et al. 2003a).

To investigate the palaeoclimatology and the evolution of the Haushi sea in Interior Oman a combination of $\mathrm{O}, \mathrm{C}$, and $\mathrm{Sr}$ isotopes was used on bed-by-bed-collected brachiopod shells within the Saiwan Formation. The degree of diagenetic alteration and rejected shells not meeting strict preservation criteria was assessed. Spiriferids and spiriferinids show better preservation of the fibrous secondary layer than do orthotetids and productids, whose laminar secondary layer is usually altered and/or luminescent. Spiriferids are the most suitable for isotopic analysis.

Three sets of isotope data $(\mathrm{C}, \mathrm{O}$ and $\mathrm{Sr})$ are consistent with two possible scenarios. In an open ocean setting, the carbon and oxygen would suggest maximum deglaciation within the base of the Saiwan and then a return to glacial conditions elsewhere in Gondwana, which however it is not generally supported by the sedimentology and palaeontology of
Gondwanan regions (SE Australia) and by published smoothed curves. There is a suggestion in the data of Korte et al. (2005) that there are minor irregularities in the unsmoothed curve that may account for the upturn in the Saiwan. The Sr isotope data does not conform to the published seawater curve for the Sakmarian, but as this is based on extrapolation between a few data points, it is possible that the $\mathrm{Sr}$ does reflect open ocean in this region. Alternatively, the upturn in the oxygen isotope data may reflect evaporation, implying a restricted Haushi basin south of the Neotethys rift shoulder, in which case the variation in $\mathrm{Sr}$ isotope composition may reflect a fluvial component. The $\mathrm{Sr}$ concentration would increase with evaporation, but the isotope ratio would not change. The trend towards higher $\delta^{13} \mathrm{C}$ may indicate increasing aridity and oligotrophy. This second scenario sounds more logical and reasonable.

\section{Acknowledgements}

We like to express our sincere thanks to C. Arrowsmith, M. Brunetti, J. Green, C. Malinverno, A. Rizzi and A. Sumner for their high level of technical expertise and help in preparing this paper. Reviews by G. Shi and A. Perez Huerta improved the manuscript.

\section{References}

Alvarez, F. 1990. Devonian athyrid brachiopods from the Cantabrain Zone (NW Spain). Biostratigraphie du Paleozoique 11, 1-311.

Angiolini, L. 2001. New syringothyridid genus (Spiriferinida, Brachiopoda) from the Early Permian of Interior Oman. Rivista Italiana di Paleontologia e Stratigrafia 107 (1), 125-30.

Angiolini, L., Bucher, H., Pillevuit, A., Platel, J. P., Roger, J., Broutin, J., Baud, A., Marcoux, J. \& Al Hashmi, H. 1997. Early Permian (Sakmarian) brachiopods from Southeastern Oman. Geobios 30 (3), 379-405.

Angiolini, L., Balini, M., Garzanti, E., Nicora, A. \& Tintori, A. 2003 a. Gondwanan Glaciation and opening of Neotethys: the Al Khlata and Saiwan formations of Interior Oman. Palaeogeography, Palaeoclimatology, Palaeoecology 196, 99-123.

Angiolini, L., Balini, M., Garzanti, E., Nicora, A., Tintori, A., Crasquin-Soleau, S. \& Mattoni, G. 2003b. Permian climatic and palaeogeographic changes in northern Gondwana: The Khuff Formation of Interior Oman. Palaeogeography Palaeoclimatology Palaeoecology 191, 269-300.

Angiolini, L., Stephenson, M. H. \& Leven, E. Ya. 2006. Correlation of the Lower Permian Surface Saiwan Formation and subsurface Haushi Limestone, Central Oman. GeoArabia 11 (3), 17-38.

Auclair, A.-C., Joachimski, M. M. \& Lécuyer, C. 2003. Deciphering kinetic, metabolic and environmental controls on stable isotope fractionations between seawater and the shell of Terebratalia transversa (Brachiopoda). Chemical Geology 202, 59-78.

Azmy, K., Veizer, J., Wenzel, B., Bassett, M. G. \& Copper, P. 1999. Silurian strontium isotope stratigraphy. Geological Society of America Bulletin 111, 475-83.

Banks, M. R. \& Clarke, M. J. 1987. Changes in the geography of the Tasmania Basin in the Late Paleozoic. In McKenzie, G. D. (ed)

Figure 8 previous page.

Figure 8 Cathodoluminescence photomicrographs: (1) Longitudinal section of a luminescent shell, showing diffusion along laminar microporosity, Derbyia haroubi, specimen OL15-23, dorsal valve; (2) Longitudinal section of a non luminescent shell, Neospirifer (Quadrospira) aff. hardmani, specimen OM47-47, ventral valve; (3) Longitudinal section of a luminescent shell, diagenetically altered through microfractures diffusion from the innerside, Neospirifer (Quadrospira) aff. hardmani, specimen OL15-140, ventral valve; (4) Longitudinal section of non luminescent shell with sparse and thin punctae, Punctocyrtella spinosa, specimen OL15-48, ventral valve; (5) Longitudinal section of a luminescent shell, Cyrtella sp. A, specimen OM48-15, ventral valve; (6) Longitudinal section showing traces of bioerosion filled by calcite cements, Neospirifer (Quadrospira) aff. hardmani, specimen OM48-14, ventral valve; (7) Longitudinal section showing rhythmic luminescent CL lines, Pachycyrtella omanensis, specimen OL14-401, ventral valve; (8) Cathodoluminescence of a bioclastic packstone (OL15). Note the homogeneous diagenetic overprint on cements $(\mathrm{C})$, bryozoans (br), and bivalves $(\mathrm{P})$. The black colour is preserved only for the brachiopod shell (B), documenting the limited effect of diagenetic overprinting on its resistant fibrous calcite. 
Gondwana Six: Stratigraphy, Sedimentology and Paleontology. Geophysical Monograph 41, 1-14. Washington, DC: American Geophysical Union.

Barbin, V. \& Gaspard, D. 1995. Cathodoluminescence of Recent articulate brachiopod shells. Implications for growth stages and diagenetic evaluation. Geobios Mem. Spec. 18, 39-45.

Birck, J. L. 1986. Precision K-Rb-Sr isotopic analysis: application to $\mathrm{Rb}-\mathrm{Sr}$ chronology. Chemical Geology 56, 73-83.

Brand, U. 1989. Global climatic changes during DevonianMississippian: stable isotope biogeochemistry of brachiopods. Palaeogeography, Palaeoclimatology, Palaeoecology 75, 311-29.

Brand, U., Logan, A., Hiller, N. \& Richardson, J. 2003. Geochemistry of modern brachiopods: applications and implications for oceanography and paleoceanography. Chemical Geology 198, 305-34.

Bruckshen, P., Oesmann, S. \& Veizer, J. 1999. Isotope stratigraphy of the European Carboniferous. Proxy signals for ocean chemistry, climate and tectonics. Chemical Geology 161, 127-63.

Carpenter, S. J. \& Lohmann, K. C. $1995 . \delta^{18} \mathrm{O}$ and $\delta^{13} \mathrm{C}$ values of modern brachiopod shells. Geochimica et Cosmochimica Acta 59, 3749-64.

Compston, W. 1960. The carbon isotopic composition of certain marine invertebrates and coals from the Australian Permian. Geochimica et Cosmochimica Acta 18, 1-22.

Curry, G. B. \& Fallick, A. E. 2002. Use of stable oxygen isotope determinations from brachiopod shells in palaeoenvironmental reconstructions. Palaeogeography, Palaeoclimatology, Palaeoecology 182, 133-43.

Denison, R. E., Koepnick, R. B., Fletcher, A., Howell, M. W. \& Callaway, W. S. 1994a. Criteria for the retention of original seawater ${ }^{87} \mathrm{Sr} /{ }^{86} \mathrm{Sr}$ in ancient shelf limestones. Chemical Geology (Isotope Geoscience Section) 112, 131-43.

Denison, R. E., Koepnick, R. B., Burke, W. H., Hetherington, E. A. \& Fletcher, A. 1994b. Construction of the Mississippian, Pennsylvanian and Permian seawater ${ }^{87} \mathrm{Sr} /{ }^{86} \mathrm{Sr}$ curve. Chemical Geology (Isotope Geoscience Section) 112, 145-67.

Dickins, J. M. 1996. Problems of a Late Palaeozoic glaciation in Australia and subsequent climate in the Permian. Palaeogeography, Palaeoclimatology, Palaeoecology 125, 185-97.

Dubreuilh, J., Béchennec, F., Berthiaux, A., Le Métour, J., Platel, J.-P., Roger, J. \& Wyns, R. 1992. Geological map of Khaluf, Sheet NF 40-15, scale 1:250,000 and explanatory notes. Muscat: Directorate General of Minerals, Oman Ministry of Petroleum and Minerals.

Ebneth, S., Shields, G. A., Veizer, J., Miller, J. F. \& Shergold, J. H. 2001. High-resolution strontium isotope stratigraphy across the Cambrian-Ordovician transition. Geochimica et Cosmochimica Acta 65 (14), 2273-92.

England, J., Cusack, M., Paterson, N. W., Edwards, P., Lee, M. R. \& Martin, R. 2006. Hyperspectral cathodoluminescence imaging of modern and fossil carbonate shells. Journal of Geophysical Research 111, G03001, doi:10.1029/2005JG000144.

Fielding, C., Frank, T. D., Birgenheier, L., Thomas, S., Rygel, M. \& Jones, A. 2005. Revised Permian glacial record of Eastern Australia. Geological Society of America Abstracts with Programs 37 (7), 256. 2005 Salt Lake City Annual Meeting (October 16-19, 2005).

Frank, T. D., Jones, A., Fielding, C. \& Thomas, S. 2005. Protracted glacial conditions in eastern Gondwana maintained by strengthened upwelling during marine highstands. Geological Society of America Abstracts with Programs 37 (7), 256. 2005 Salt Lake City Annual Meeting (October 16-19, 2005)

Gaetani, M., Angiolini, L., Garzanti, E., Jadoul, F., Leven, E. Ya., Nicora, A. \& Sciunnach, D. 1995. Permian stratigraphy in the northern Karakorum (Pakistan). Rivista Italiana di Paleontologia e Stratigrafia 101 (2),107-52.

Gradstein, F. M., Ogg, J. G. \& Smith, A. G. 2004. A Geologic Time Scale, 589 pp. Cambridge: Cambridge University Press.

Grossman, E. L., Zhang, C. \& Yancey, T. E. 1991. Stable isotope stratigraphy of brachiopods from Pennsylvanian shales in Texas. Geological Society of America Bulletin 103, 953-65.

Grossman, E. L., Mii, H. S., \& Yancey, T. E. 1993. Stable isotopes in late Pennsylvanian brachiopods from the United States: implications for Carboniferous paleoceanography. Geological Society of America Bulletin 105, 1284-96.

Hudson, R. G. S. \& Sudbury, M. 1959. Permian Brachiopoda from south-east Arabia. Notes et mémoires sur le Moyen-Orient. Muséum National d'Histoire Naturelle Paris 7, 19-55.

Joachimiski, M. M., Simon, L., van Geldern, R. \& Lécuyer, C. 2005. Boron isotope geochemistry of Paleozoic brachiopod calcite: Implications for a secular change on the boron isotope geochem- istry of seawater over the Phanerozoic. Geochimica et Cosmochimica Acta 69, 4035-44.

Konert, G., Abdulkader, M. A., Al-Hajri, A. A. \& Droste, H. J. 2001. Paleozoic stratigraphy and hydrocarbon habitat of the Arabian Plate. GeoArabia 6, 407-42.

Korte, C., Kozur, H. W., Bruckschen, P. \& Veizer, J. 2003. Strontium isotope evolution of Late Permian and Triassic seawater. Geochimica et Cosmochimica Acta 67, 47-62.

Korte, C., Jasper, T., Kozur, H. W. \& Veizer, J. 2005. $\delta^{18} \mathrm{O}$ and $\delta^{13} \mathrm{C}$ of Permian brachiopods: A record of seawater evolution and continental glaciation. Palaeogeography, Palaeoclimatology, Palaeoecology 224, 333-51.

Le Métour, J., Béchennec, F., Platel, J. P. \& Roger, J. 1994. Late Permian birth of the Neo-Tethys and development of its Southern continental Margin in Oman. The Middle East Petroleum Geosciences, Selected Middle East papers from the Middle East Geosciences Conference, 643-54. Bahrain, April 1994, 2.

Leven, E. Ya 1993. Early Permian fusulinids from the Central Pamir. Rivista Italiana di Paleontologia e Stratigrafia 99 (2), 151-98.

Leven, E. Ya. 1997. Permian Stratigraphy and Fusulinida of Afghanistan with Their Paleogeographic and paleotectonic Implications. Geological Society of America Special Paper 316, 1-134.

Lowestam, H. A. 1961. Mineralogy, O18/O16 ratios, and strontium and magnesium contents of recent and fossil brachiopods and their bearing on the history of the oceans. Journal of Geology $\mathbf{6 9}$, 241-60.

Martin, E. E. \& McDougall, J. D. 1995. Sr and Nd isotopes at the Permian/Triassic boundary: a record of climate change. Chemical Geology 125, 73-99.

Martini, I. P. \& Banks, M. R. 1989. Sedimentology of the cold-climate, coal bearing, Lower Permian, Lower Freshwater Sequence of Tasmania. Sedimentary Geology 64, 25-41.

McArthur, J. M., Crame, J. A. \& Thirlwall, M. F. 2000. Definition of Late Cretaceous stage boundaries in Antarctica using strontium isotope stratigraphy. The Journal of Geology 108, 623-40.

McArthur, J. M. \& Howarth, R. J. 2004. Strontium isotope stratigraphy. In Gradstein, F. M., Ogg, J. G. \& Smith, A. G. (eds.) A geological time scale 2004, 96-105. Cambridge: Cambridge University Press.

McKinnon, D. I. 1974. The shell structure of Spiriferide Brachiopoda. The Bulletin of the British Museum (Natural History) Geology 25 (3), 189-261

Osterloff, P. L., Al-Harthy, A., Penney, R., Spaak, P., Al-Zadjali, F., Jones, N. S., O’B Knox, R. W., Stephenson, M. H., Oliver, G. \& Al-Husseini, M. I. 2004. Depositional sequences of the Gharif and Khuff Formations, subsurface Interior Oman. In Al-Husseini, M. I. (ed.) Carboniferous, Permian and Early Trissic Arabian stratigraphy. GeoArabia Special Publication 3, 149-83. Manama, Bahrain: Gulf PetroLink.

Parkinson, D., Curry, G. B., Cusack, M. \& Fallick, A. E. 2005. Shell structure, patterns and trends of oxygen and carbon stable isotopes in modern brachiopod shells. Chemical Geology 219, 193-235.

Perez Huerta, A. \& Sheldon, N. D. 2006. Pennsylvanian sea level cycles, nutrient availability and brachiopod palaeoecology. Palaeogeography, Palaeoclimatology, Palaeoecology 230, 264-79.

Popp, B. N., Anderson, T. F. \& Sandberg, P. A. 1986. Brachiopods as indicators of original isotopic compositions in some Paleozoic limestones. Geological Society of America Bulletin 97, 1262-9.

Pufahl, P. K., James, N. P., Kyser, T. K., Lukasik, J. J. \& Bone, Y. 2006. Brachiopods in epeiric seas as monitors of secular changes in ocean chemistry: a Miocene example from the Murray Basin, South Australia. Journal of Sedimentary Research 76, 926-41, doi: 10.2110/jsr.2006.079.

Samtlemben, C., Munnecke, A., Bickert, T. \& Pätzold, J. 2001. Shell succession, assemblage and species dependent effects on C/Oisotopic composition of brachiopods - examples from the Silurian of Gotland. Chemical Geology 175, 61-107.

Stephenson, M. H. \& Osterloff, P. L. 2002. Palynology of the deglaciation sequence represented by the Lower Permian Rahab and lower Gharif members, Oman. AASP Contribution Series 40, $1-41$.

Stephenson, M. H., Leng, M. J., Vane, C. H., Osterloff, P. L. \& Arrowsmith, C. 2005. Investigating the record of Permian climate change from argillaceous sediments, Oman. Journal of the Geological Society, London 162, 1-11.

Stephenson, M. H., Angiolini, L. \& Leng, M. L. In press. Relating the fossil record to deglaciation in the Early Permian of Gondwana: a review. In Williams, M., Haywood, A., Gregory, J. \& Schmidt, D. (eds) Deep time perspectives on climate change. Marrying the signal 
from computer models and biological proxies. London: The Micropalaeontological Society and the Geological Society Publishing House.

Steuber, T. \& Veizer, J. 2002. Phanerozoic record of plate tectonic control of seawater chemistry and carbonate sedimentation. $G e-$ ology 30, 1123-6.

Tomašovych, A. \& Farkaš, J. 2005. Cathodoluminescence of Late Triassic terebratulid brachiopods: implications for growth patterns. Palaeogeography, Palaeoclimatology, Palaeoecology 216, 215-33.

Veizer, J., Fritz, P. \& Jones, B. 1986. Geochemistry of brachiopods: oxygen and carbon isotopic records of paleozoic oceans. Geochimica et Cosmochimica Acta 50, 1679-96.

Veizer, J., Bruckschen, P., Pawellek, F., Diener, A., Podlaha, O. G., Carden, G. A. F., Jasper, T., Korte, C., Strauss, H., Azmy, K. \& Ala, D. 1997. Oxygen isotope evolution of Phanerozoic seawater. Palaeogeography, Palaeoclimatology, Palaeoecology 132, 159-72.
Veizer, J., Ala, D., Azmy, K., Bruckschen, P., Buhl, D., Bruhn, F., Carden, G. A. F., Diener, A., Ebneth, S., Godderis, Y., Jasper, T., Korte, C., Pawellek, F. Podlaha, O. G. \& Strass, H. 1999. ${ }^{87} \mathrm{Sr} /{ }^{86} \mathrm{Sr}, \delta^{18} \mathrm{O}$ and $\delta^{13} \mathrm{C}$ evolution of Phanerozoic seawater. Chemical Geology 161, 59-88.

Williams, A. 1966. Growth and structure of the shell of living articulate brachiopods. Nature 211, 1146-8.

Williams, A. 1968. Evolution of the shell structure of articulate brachiopods. Special Papers in Palaeontology 2, 1-55.

Williams, A. 1971. Scanning electron microscopy of the calcareous skeleton of fossil and living Brachiopoda. In Heywood, V. H. (ed.) Scanning Electron Microscopy. Systematic and Evolutionary Applications, 37-66. London \& New York: Academic Press.

Williams, A., Brunton, C. H. C., Carlson, S. J. et al. (44 authors) 1997. Treatise on invertebrate palaeontology (part $\mathrm{H}$, Brachiopoda revised). Volume 1: Introduction, $539 \mathrm{pp}$. Boulder, Colorado and Lawrence, Kansas: Geological Society of America and University of Kansas Press.

MS received 12 August 2006. Accepted for publication 10 September 2007. 